$$
\text { فتح المنان في شرح الحديث : "..... }
$$

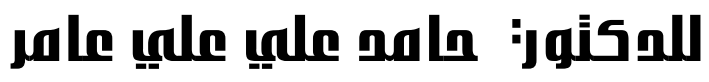

الأستاذ الهساعد قسه, الحديث وعلومه- كليت أصول الدين

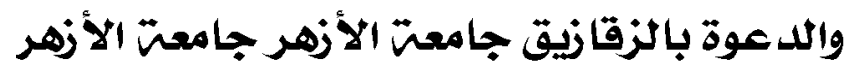


فتح المنان في شرح الحديث : "..... إنهما يعذبان .... "دراسة حديثية تحليلية موضوعية ـ 


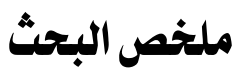

هذا حديث مثفق عليه، بمس قضايا عقدية شرعية غاية في الأهمية ، وهــــو

يؤ كد في المقام الأول حرص رسول الله - صلى اللّ عليه وسلم -علي أمته ، فهو

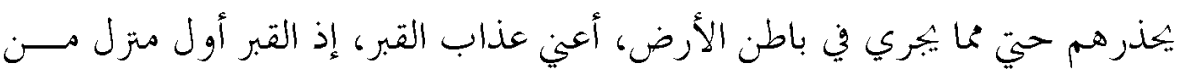

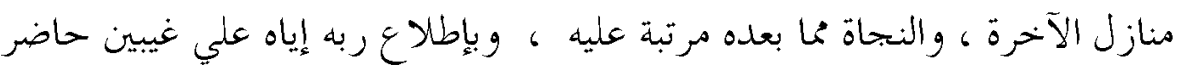

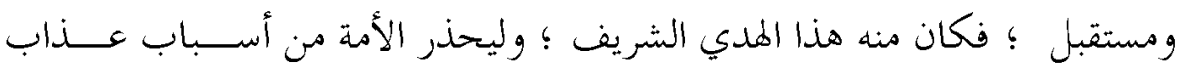

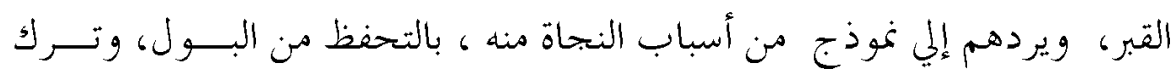
الإفساد بين الناس، ووضع كل رطب على القبر رجاء التخغيف.

Fatah al-Manan in explaining the hadith: they torment an objective and analytical hadith study. This summary is an agreed upon hadith that touches on issues of a very important legal doctrine, and it confirms in the first place the

$\overline{3}$ concern of the Messenger of God towards his nation, as he warns them even about what is happening in the ground I mean the torment of the grave, as the grave is the first of the houses of the Hereafter, and deliverance from what comes after it is arranged upon him and peace and his Lord revealed it to him in two present and future visions, so this honorable guidance was from him, and to warn the ummah of the causes of the torment of the grave, and to return them to an example of the causes of salvation from it, by guarding against urine And leave corruption among the people, and put all damp ones in the grave, please lighten up. 


\section{فتح المنان في شرح الحديث : "..... إنهما يعذبان .... "دراسة حديثية تحليلية موضوعية ـ}

\section{مقدمة}

الحمد للّه رب العالمين ، الرحمن الرحيم ، مالك يوم الدين ، و الصــلاة والســالحم

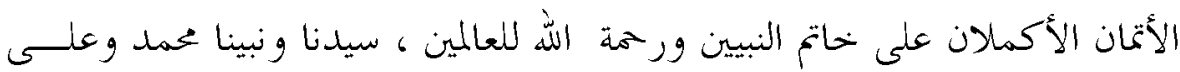
آله وصحبه أجمعين.

\section{و بعد :}

فهذا بكث حديثي تحليلي موضوعي ، أتناول فيه الحديث الذي رواه عبدالله بن

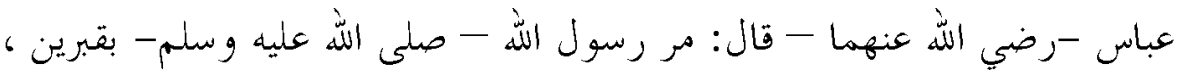

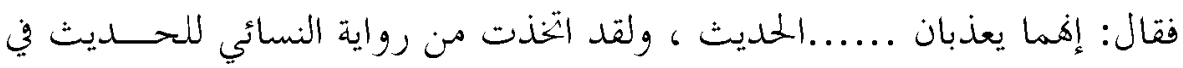

سننه أصلا لتناوله ، و كان هذا الحمديث موضو ع هذا البحث للأسباب التالية: 1- لم أقف - كي حدود علمي- على بحث شاف واف فيه.

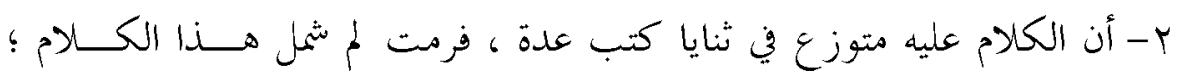
لتكتمل الفائدة للقارئ.

r- إثتمال الحديث على قضايا عقدية وفقهية غاية في الأهمية.

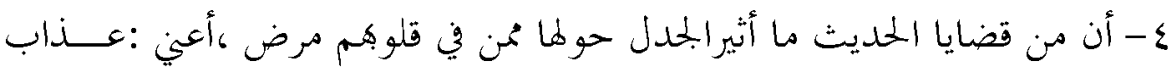
القبر؛ فعزمت أن أدلي بدلوي مسهما في الدفاع عن العقيدة من منظور السنة.

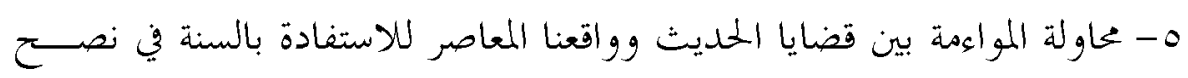
الأمة.

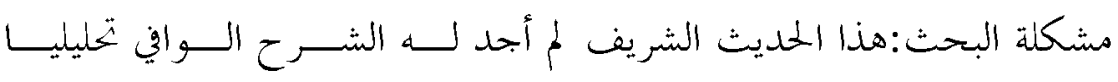

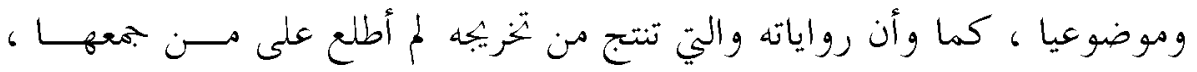

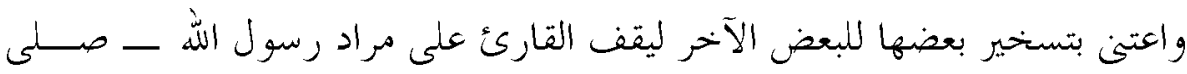

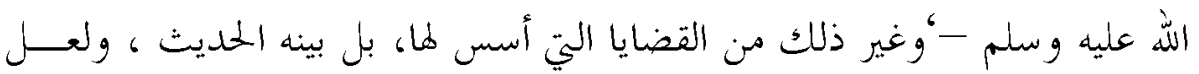

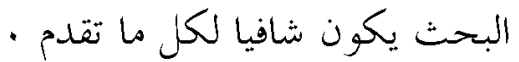




\section{فتح المنان في شرح الحديث :".... إنهما يعذبان ...."دراسة حديثية تحليلية موضوعية}

منهج البحث :بالأصالة هو منهاج الحدثين ، ولقد اتبعت في هــــا البحــث

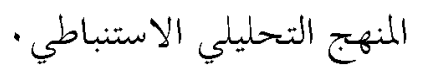

هذا ، وخطة البحث تشتمل على مقدمة ، وأربعة مباحسـث ، وخاتمــة ،

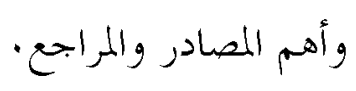

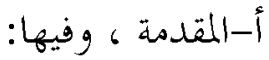

$$
\begin{aligned}
& \text { 1-أسباب اختيار الموضوع . } \\
& \text { Y-مشكلة البحث . } \\
& \text { ب-منهج البحث. } \\
& \text { ب-المباحث ، وهي : }
\end{aligned}
$$

المبحث الأول:ذكر الرواية الأصل ، مع التخريج ·

$$
\text { المبحث الثاني:لطائف الإسناد. }
$$

المبحث الثالث: لغة الحديث .

المبحث الرابع : قضايا الحديث .

$$
\text { ج-الخاتمة ، وفيها }
$$

أ- نتائج البحث و التوصيات.

$$
\text { ب -أهم المصادروالمراجع. }
$$




\section{المبحثث الأول}

\section{ذكر الرواية الأصل ، مع التخريج .}

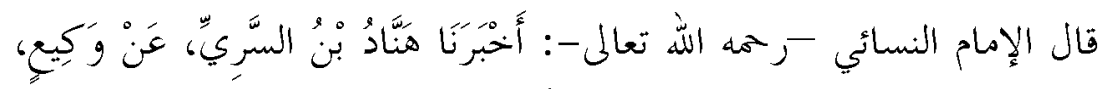

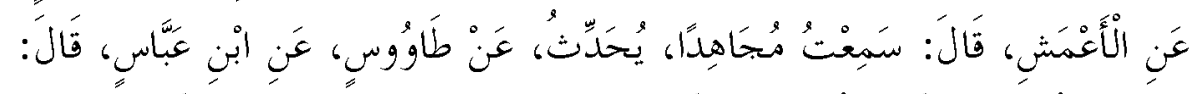

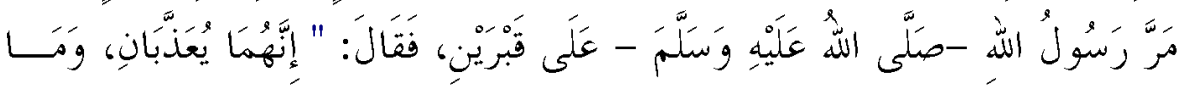

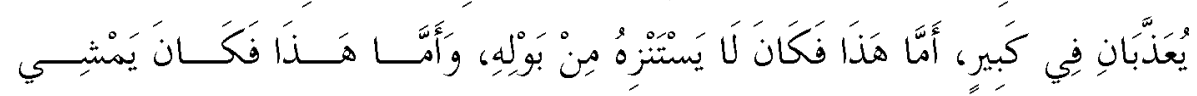

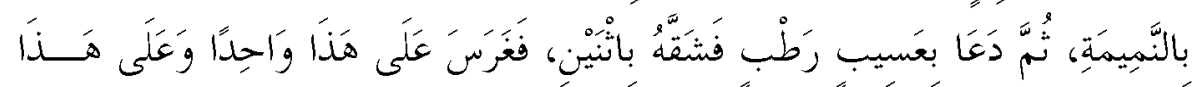

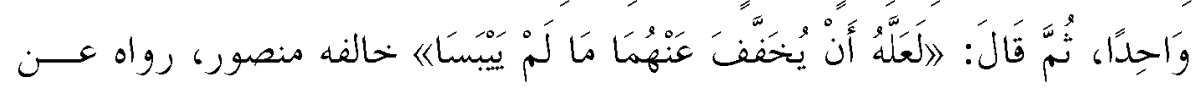
بحاهد عن ابن عباس ، و ولم يذكر طَأوُوسًا.

ا-أخرجه الإمام النسائي في سنه الصغرى كتاب الطهــارة بـــاب الــتنزه مـــن

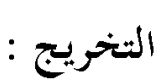

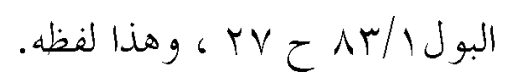

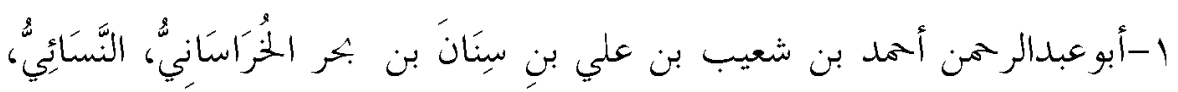
Is

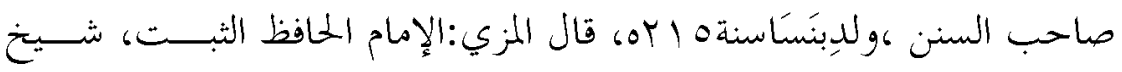

$$
\text { الإسلام ناقد الحديث، مات سنة بـ به (1). }
$$

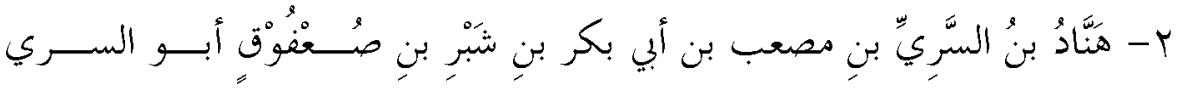

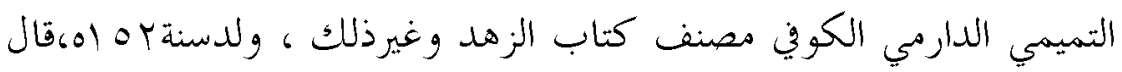

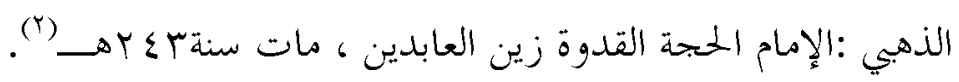




\section{فتح المنان في شرح الحديث : ".... إنهما يعذبان ...."دراسة حديثية تحليلية موضوعية}

r-و كيع بن الجراح بن عدي بن فرس أبو سفيان الرؤاسي ، قال ابــن معسيـن :

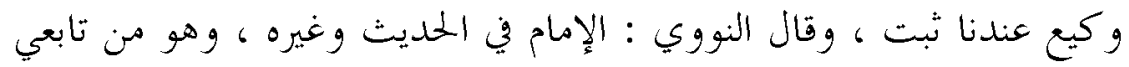

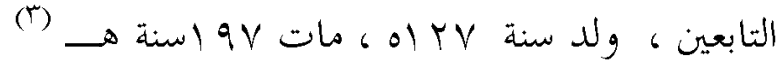

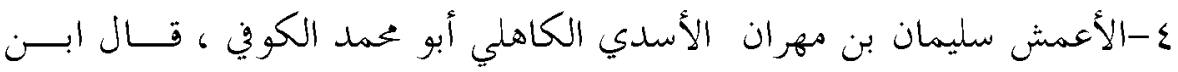

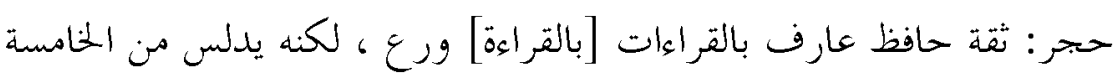

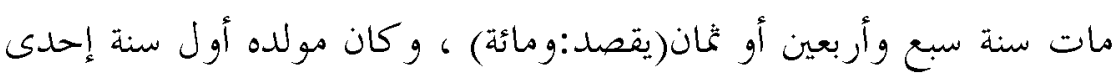

(\&) و ستين

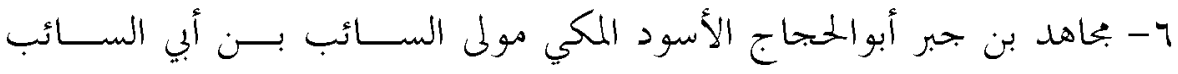

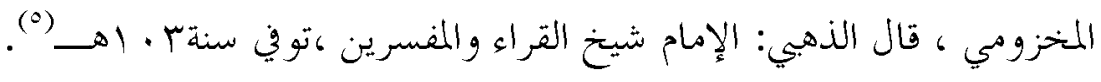

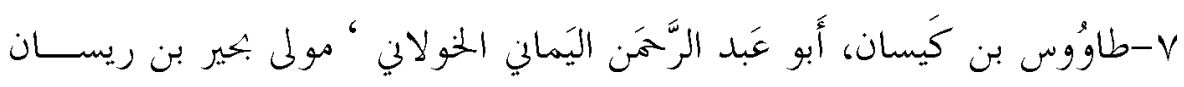

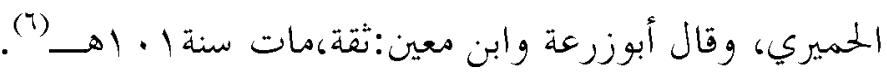

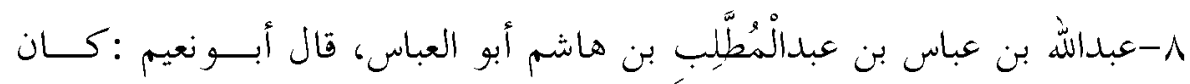

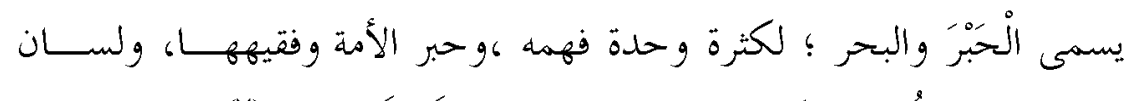

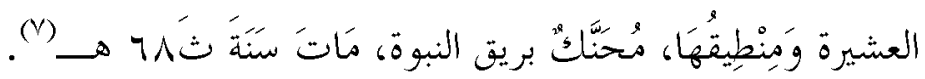

الحمكم على إسناد الحديث : صحيح ورجاله ثُقات . 
فتيح المنان في شرح الحديث : "..... إنهما يعذبان .... "دراسة حديثية تحليلية موضوعية -

\section{口المبحث الثاذي \\ لطائف الإسناد}

·- أنه من سداسيات النسائي

Y-أن فيه صيغ الأداء:الإخبار ، والعنعنة ، والسماع ، والقول . r-أن رواته كلهم أجلاء ثقات.

ع-أن الثلاثة الأولين كوفيون ، والرابع مكي، والخامس بماني، والصحابي مكـي، ملني، بصري، طائفي.

- مأن فيه رواية ثلاثة من التابعين بعضهم عن بعض (م). التخريج:قلت: والحديث أخرجهه:

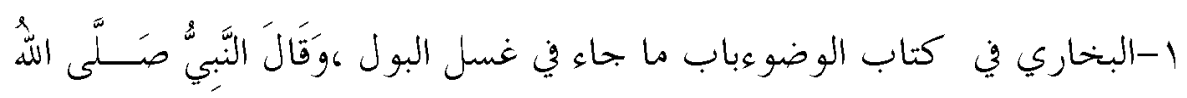

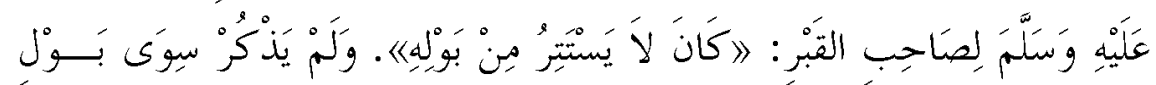

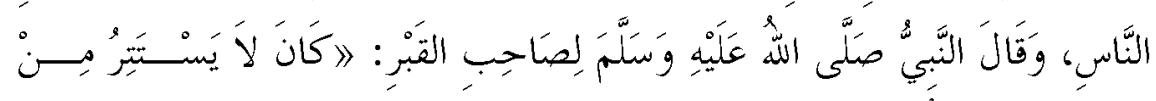

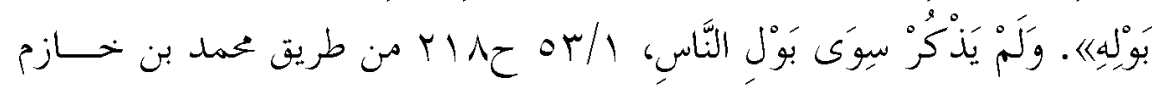

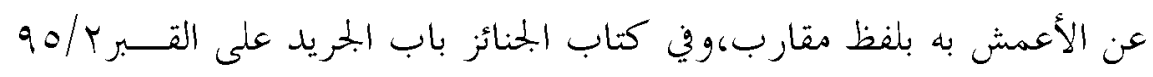

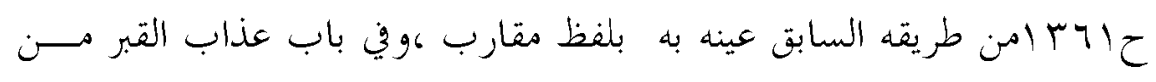

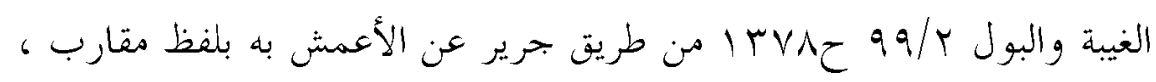

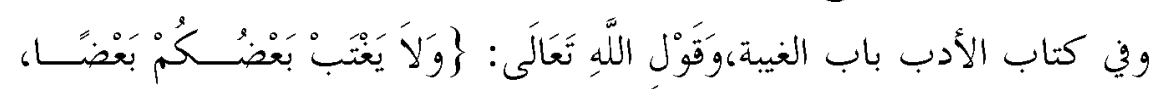

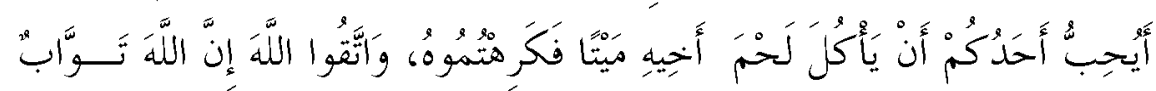

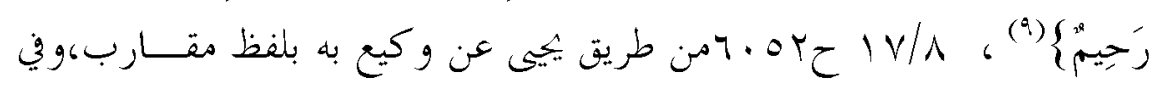

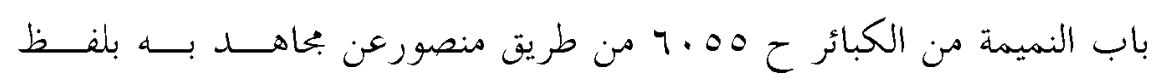

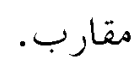




\section{فتح المنان في شرح الحديث :".... إنهما يعذبان ...."دراسة حديثية تحليلية موضوعية}

Y-مسلم في صحيحه في كتاب الطهارة باب الاستتار مــن البــول والاســتـراه

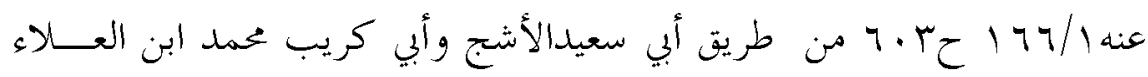

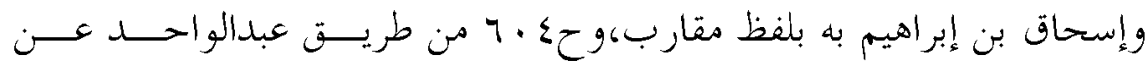
سليمان الأعمش به بلغظه.

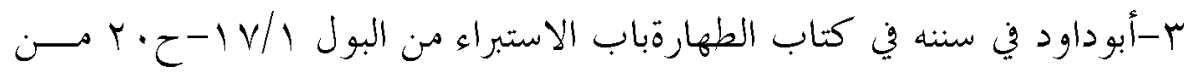

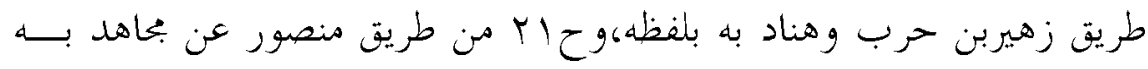
بلفظه كوا إسناداه صحيحان.

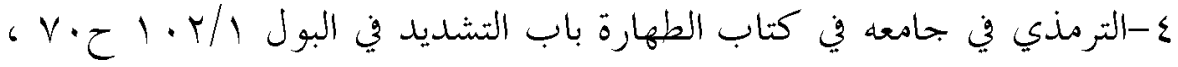
من طريق هناد به مختصراهومن طريق أبي كريب وقتيبة عن وكيع به مختصــرا.

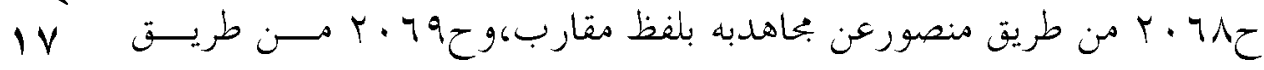
هنادبن السري به بلفظ مقارب كوإسناداه صحيحان .

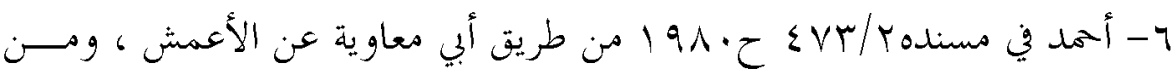

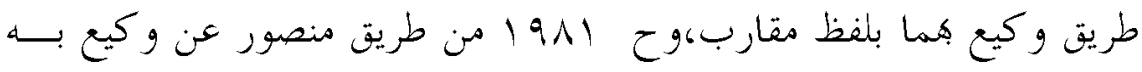
بلفظ مقارب ، وأسانيده صحيحة.

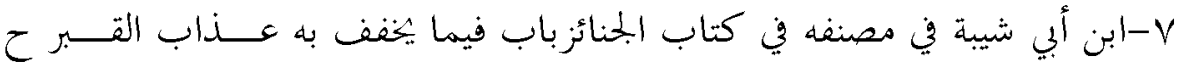

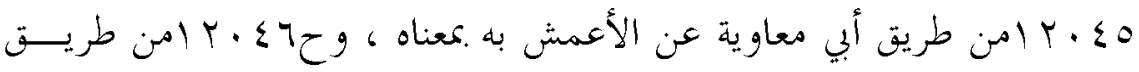
و كيع به .معناه، وإسناداه صحيحان .

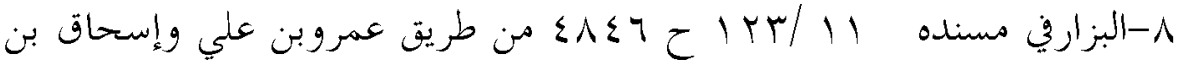
إبراهيم بن حبيب به بلغظ مقارب .

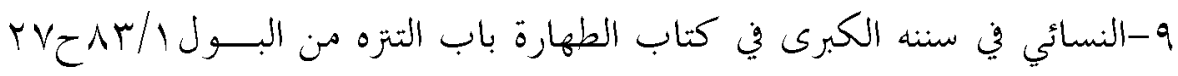
من طريق هناد بن السري به بلفظه ، وفي كتاب الجنائز باب وضع الجريدة على 


\section{فتح المنان في شرح الحديث : "..... إنهما يعذبان .... "دراسة حديثية تحليلية موضوعية -}

القبر/YV

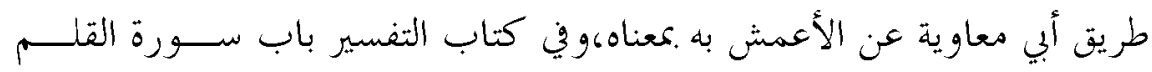

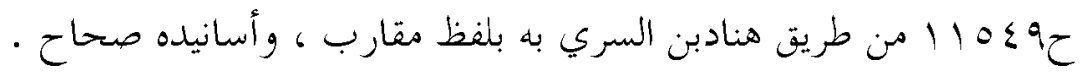
•ا-ابن الجلارود في المنتقى في كتاب الطهارة باب التنزه في الأبدان والثياب عن

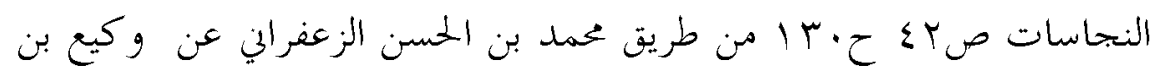
الجراح به بلفظ مقارب.

| الطوسي في مستخرجه على جامع الترمذي في باب ما جاء في التشــــديد في

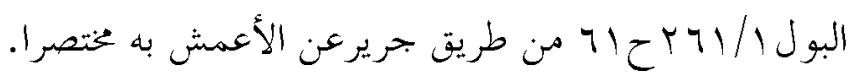

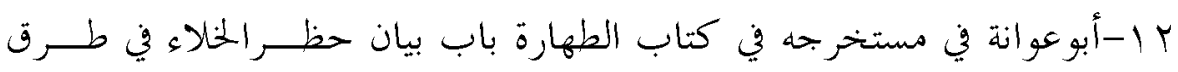

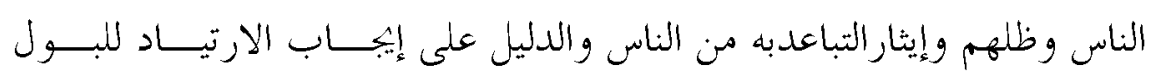

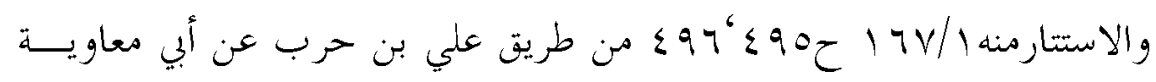
وو كيع عن الأعمش به ،ومن طريق عبدالواحد بن زياد عن الأعمش به ، كلهم

با ا-الطحاوي في مشكل الآثار باب بيان مشكل ما روي عن رسول الله صلى

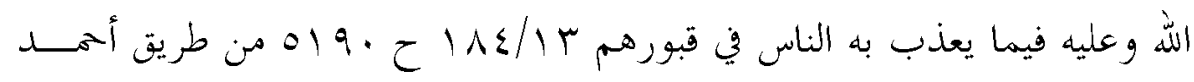
ابن شعيب عن هناد بن السري به بلفظه.

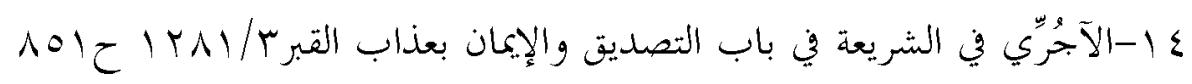
من طريق أبي معاوية عن الأعمش به ،ومن طريق يوسف ابن موسى القطان عن

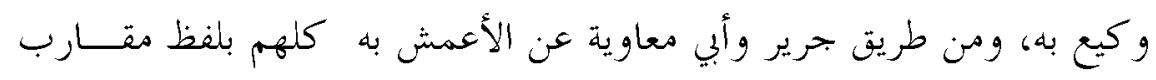

$$
\text { مختصرا. }
$$

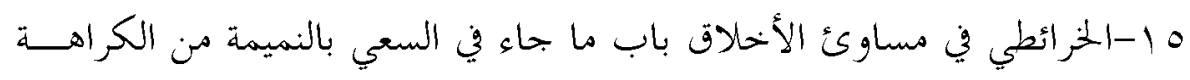

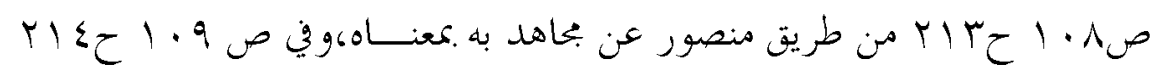
من طريق حبيب بن حسان الكوفي عن بحاهد أبي الحجاج به بمعناه ،وزيادة فيه. 
ـ- فتح المنان في شرح الحديث :".... إنهما يعذبان ...."دراسة حديثية تحليلية موضوعية

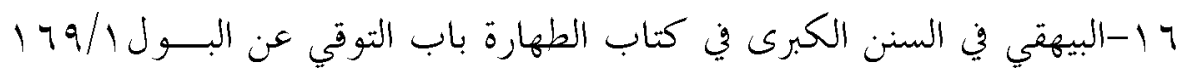

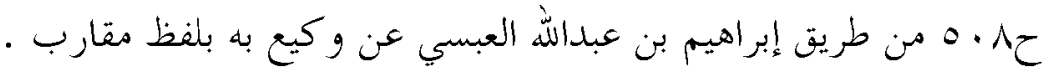

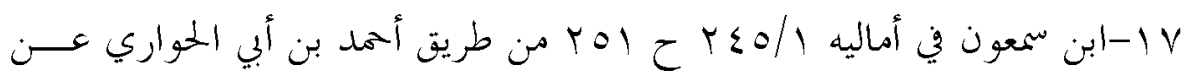

وكيع به بلفظ مقارب.

$\frac{3}{3}$

$\overline{3}$ 


\section{المبحث الثالث}

\section{لغة الحلديث}

قول ابن عباس -رضي الله عنهما- : مر رسول الله- صلى الله عليه وسلممر عليه يمر مراومرورا:جاز ، ومر مراومرورا ذهب ، وقال ابن سيده: مر يمر مرا

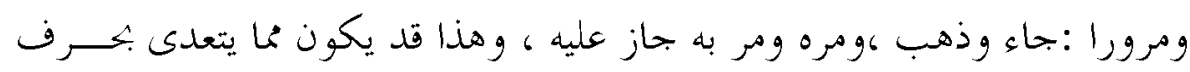

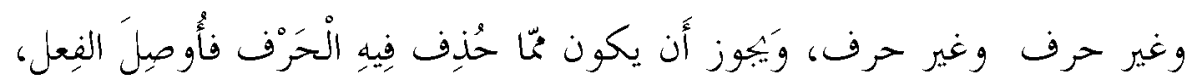

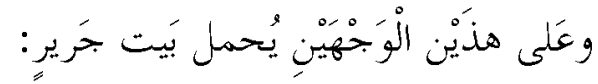

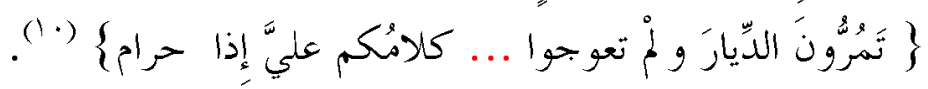

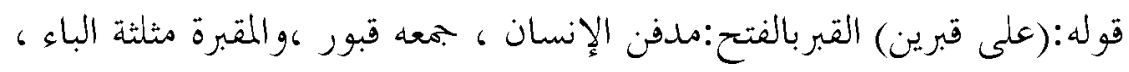
وكمكنسة:موضعها، أي القبور. (11)

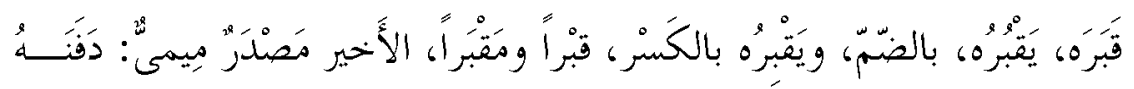

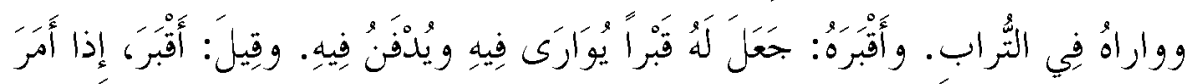

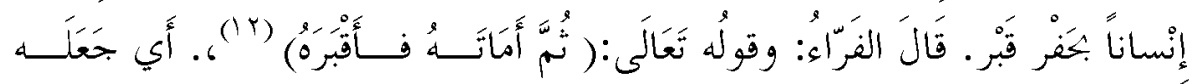

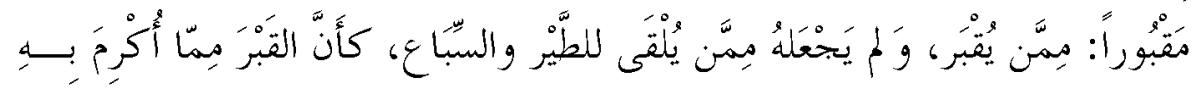

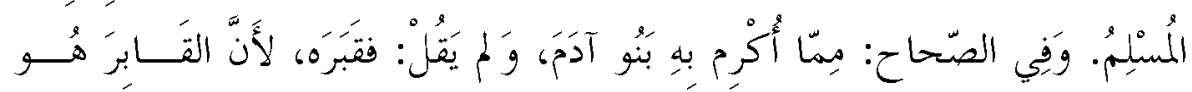

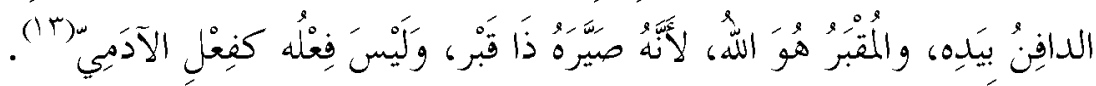

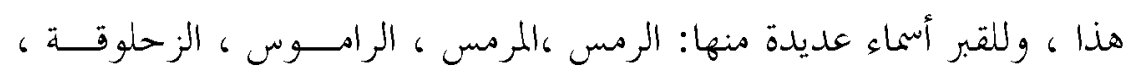

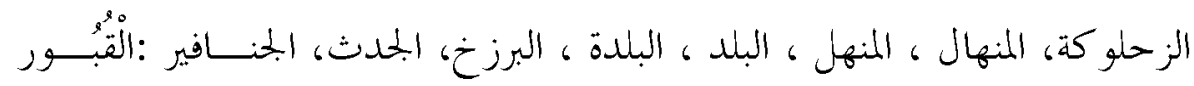

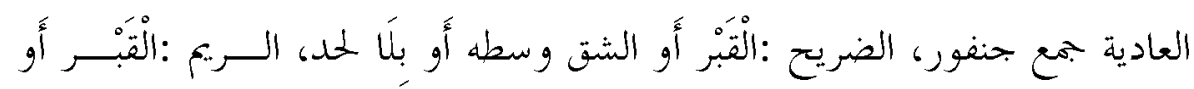

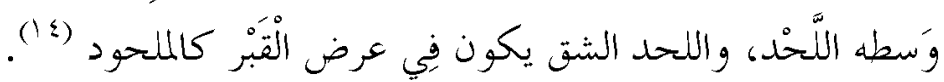

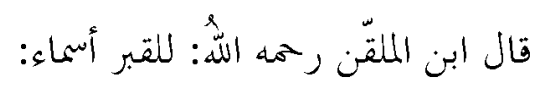

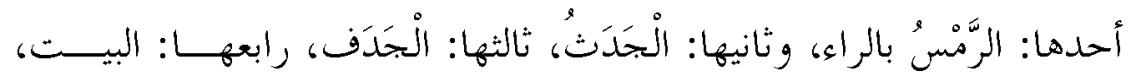

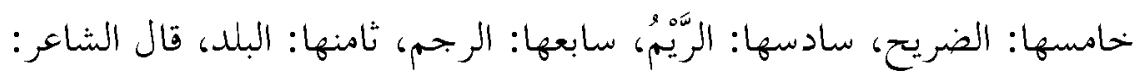




\section{فتح المنان في شرح الحديث :".... إنهما يعذبان ...."دراسة حديثية تحليلية موضوعية}

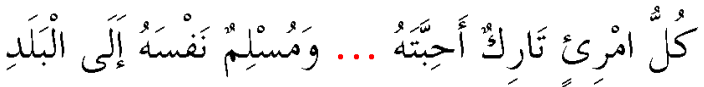

$$
\begin{aligned}
& \text { ذكرهنّ صاحب "المخصصص ". }
\end{aligned}
$$

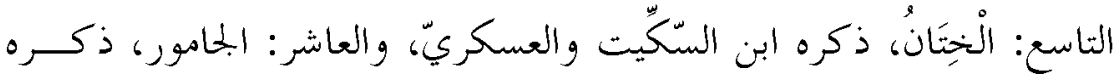
الهنائيّ في "المنتخب"، الحلادي عشر: الددس بالدال، الثاني عشر: المِنهِال، ذكرهما ابن السكّيت والعسكريّ. انتهى (10). قال الولوي :ونظمت ذلك بقولي:

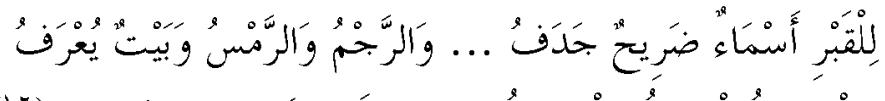

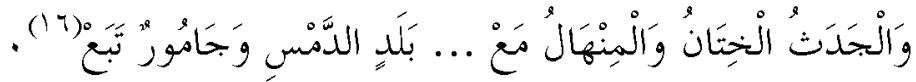

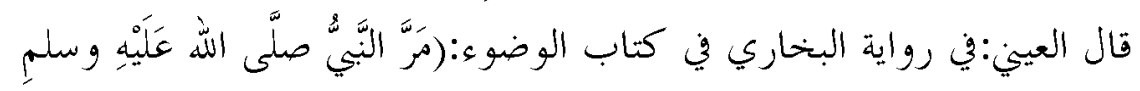

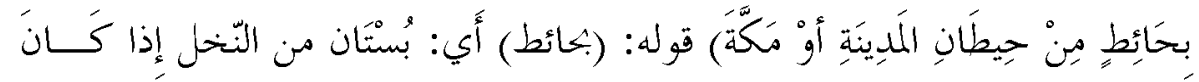

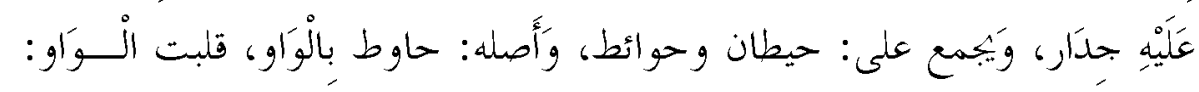

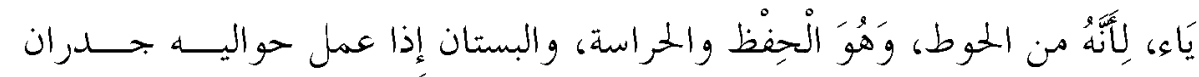

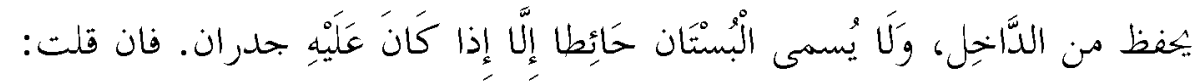

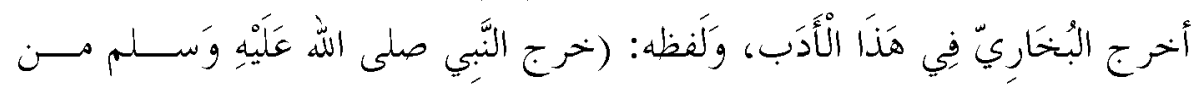

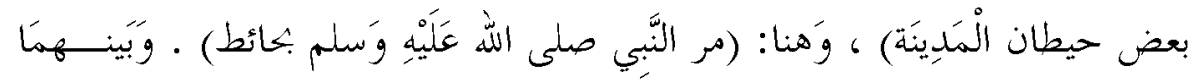

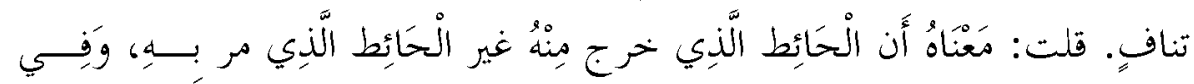

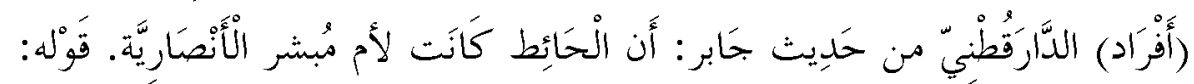

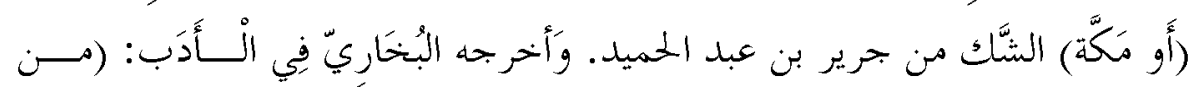

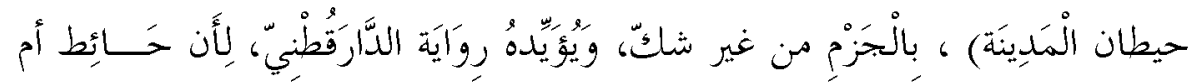

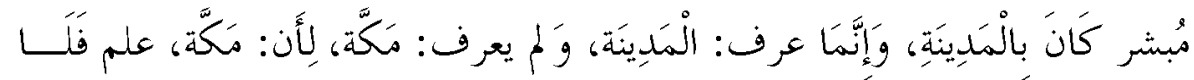

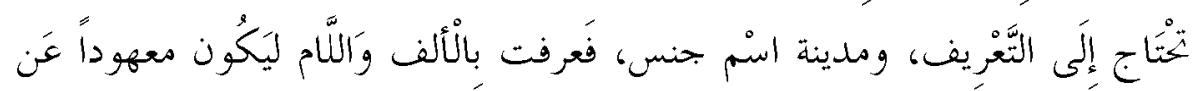

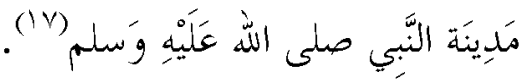




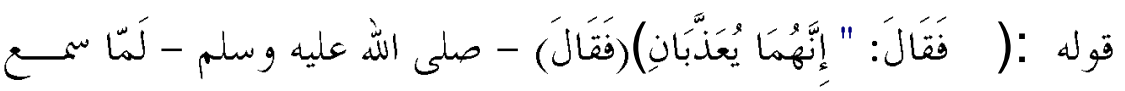

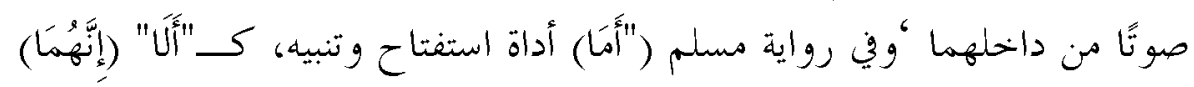

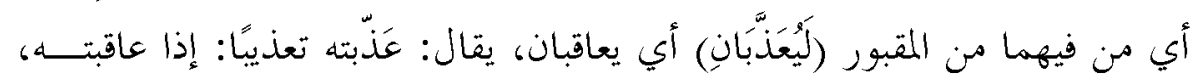

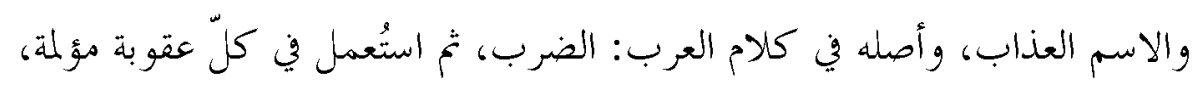

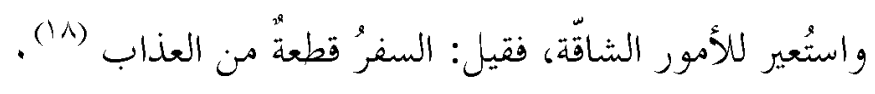

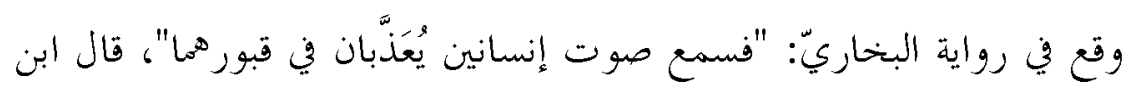

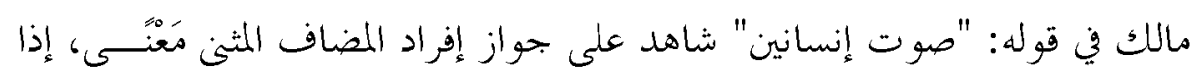

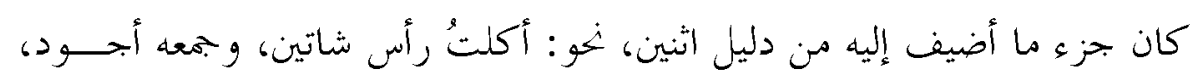

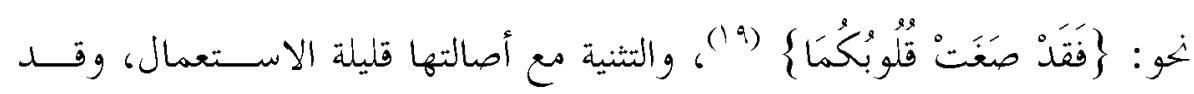
اجتمع التنية والجمع في قول الراجز:

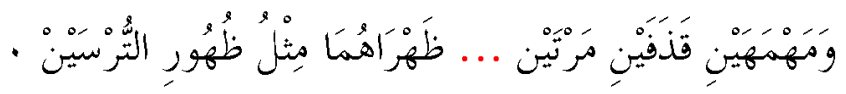

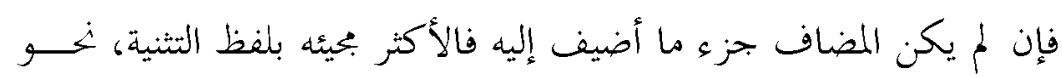

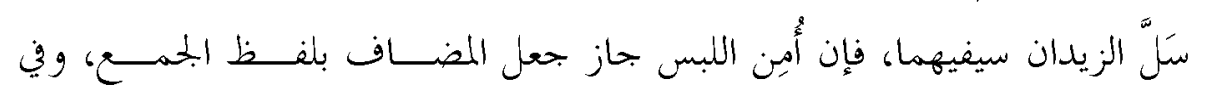

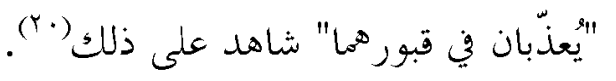

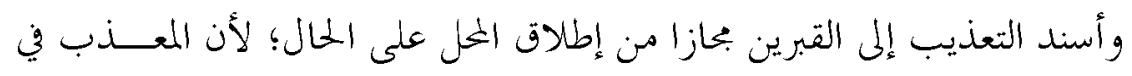
الحقيقة مَن فيهما.

ويجتمل عود الضمير على معلوم من المقام، وهو من في القبرين لأن سياق الكــلام يدل عليه.

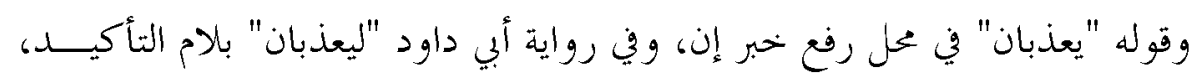

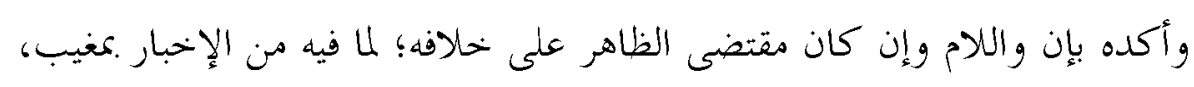

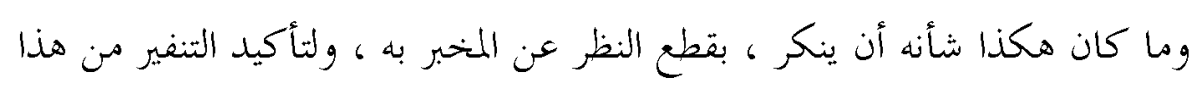

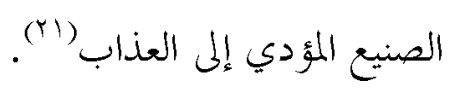


(قوله :في كبير) أى بسبب أمر كبير، ففى للسببية على حدّ: دخلت امرأة

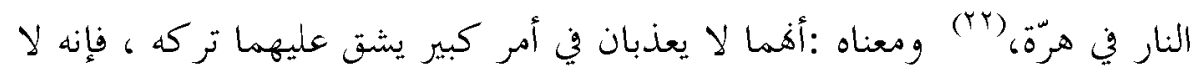

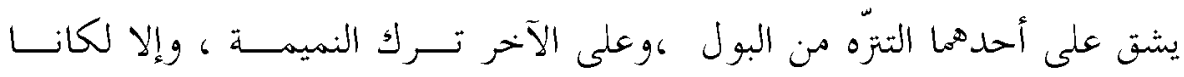

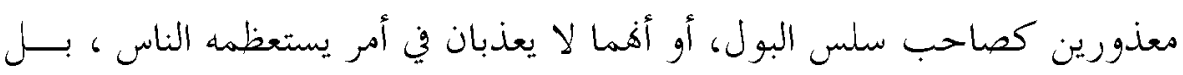

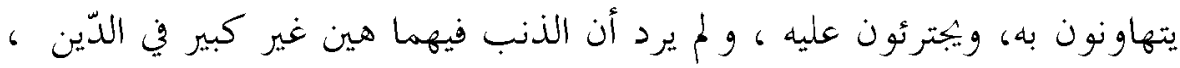

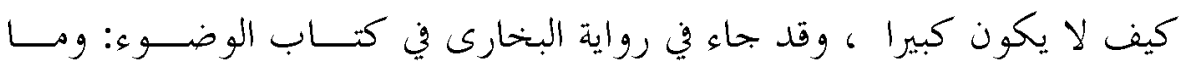

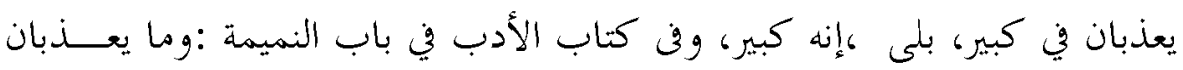
في كبير، وإنه لكبير، أى عظيم عند الله تعالى ، ومصداقه قوله تعالى (وتحســـبونه هينا وهو عند الله عظيم ) (r) .وقال القاضى عياض :معناه أنه ليس بأكبر الكبائر،

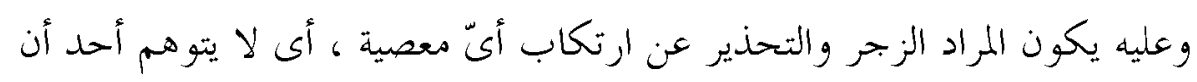

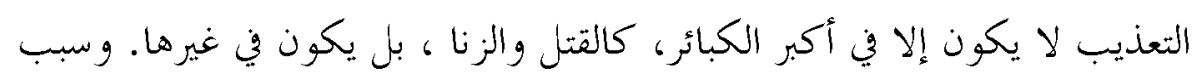

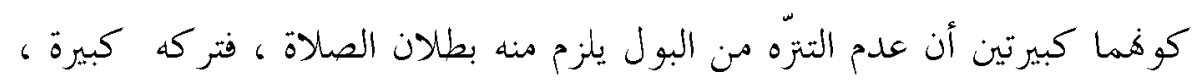

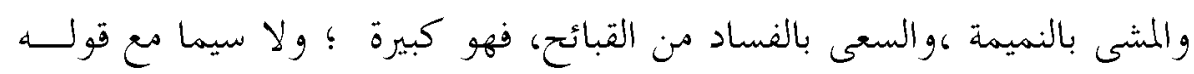

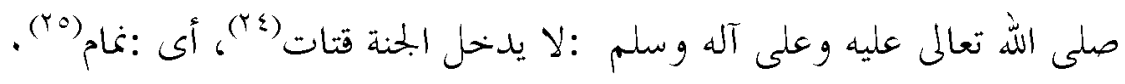

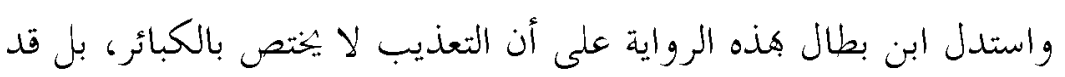
يقع على الصغائر، قال: لأن الاحتراز من البول لم يرد فيه وعيد ، يعين قبل هذه

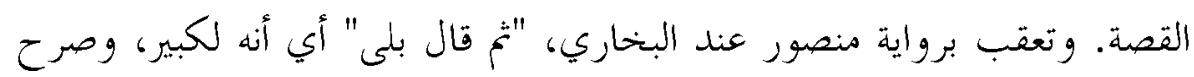

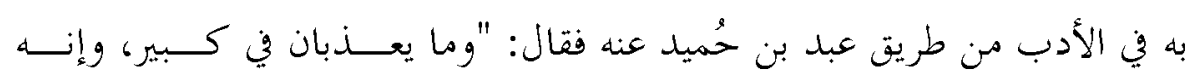

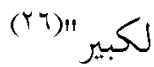

الأقوال في معنى قوله "وإنه لكبير" :

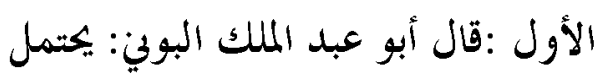
أنه - صلى الله عليه وسلم - ظن أن ذلك غير كبير، فــأوحى إليـــهـ في أله

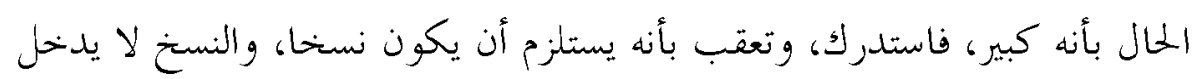




\section{فتح المنان في شرح الحديث : "..... إنهما يعذبان .... "دراسة حديثية تحليلية موضوعية -}

الخبر، وأجيب بأن الحلكم بالحبر يجوز نسخه فقوله "وما يعذبان في كبير" إخبــار بالحكم، فهذا أوحي إليه أنه كبير، فأخبر به، كان نسخا لذلك الحكمب. (Ty) الثابي:وقيل: بكتمل أن الضمير في قوله: وإنه يعود على العذاب، لما ورد في صحيح ابن حبان من حديث أبي هريرة "يعذبان عذابا شديدا في ذنب هين". الثالث:وقيل: الضمير يعود على أحد الذنبين، وهو النميمة لأكا مــن الكبـــئر، بخالف كشف العورة، وهذا مع ضعفه غير مستقيم؛ لأن الاستتار المنفي ليس المراد

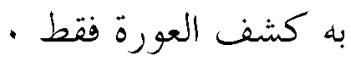

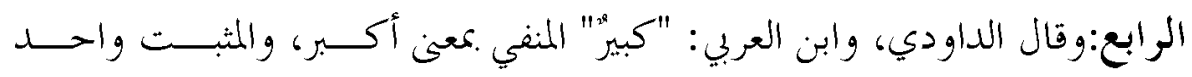
الكبائر، أي ليس ذلك بأكبر الكبائر كالقتل مثلا، وإن كان كبيرًا في الجملة. الحخامس:وقيل: المعنى ليس بكبير في الصورة لأن تعاطي ذلك يدل علــى الـــنـاءة والحقارة، وهو كبير في الذنب.

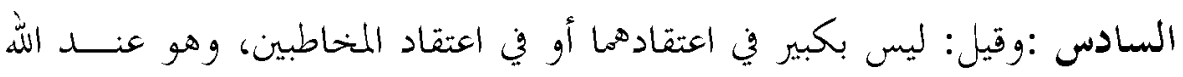

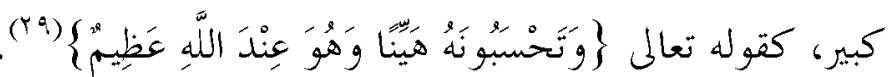
السابع:وقيل: ليس بكبير في مشقة الاحتراز، أي كان لا يشق عليهما الاحتراز من فئن ذلك وهذا الأخير جزم به البغوي وغيره، ورجحه ابن دقيق العيد، وجهاعة. الثامن:وقيل: ليس بكبير بمجرده، وإنما صار كبيرًا بالمواظبة عليه، ويرشد إلى ذلك

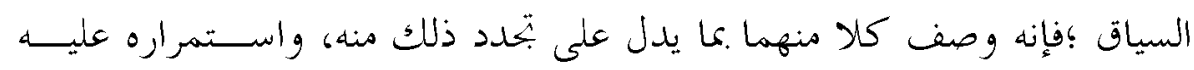

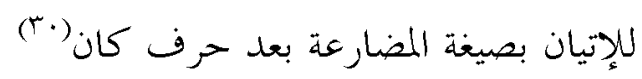

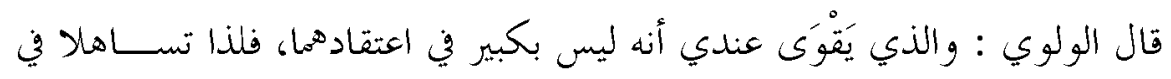
شأنه، مع أنه لا يشق عليهما الاحتراز عنه، وهو عند الله كبير، والله أعلم (آم).

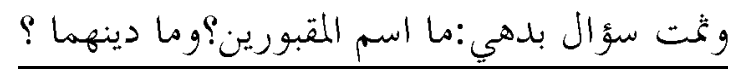
ابلجواب

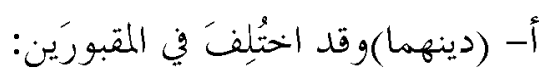




\section{فتح المنان في شرح الحديث :".... إنهما يعذبان ...."دراسة حديثية تحليلية موضوعية}

1-فقيل: كانا كافرين، وبه جزم أبو موسى المدينيّ، واحتجّ بما رواه من حسـديث

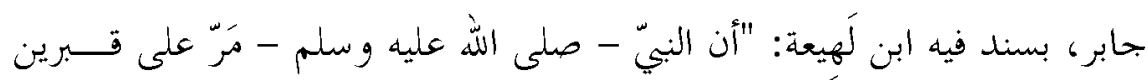

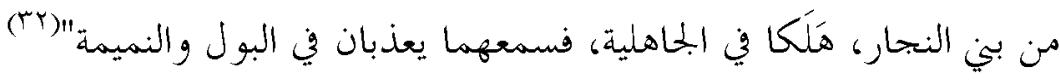
ب- قال أبو موسى: هذا وإن كان ليس بقويّ، لكن معناه صحيح، لأفما لو كانا

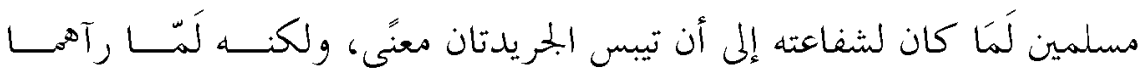

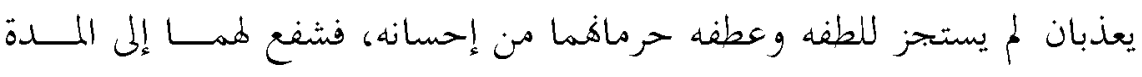
المذكورة. (r)

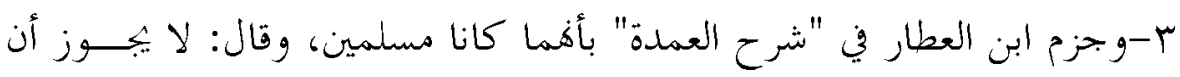

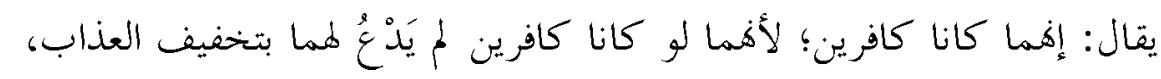

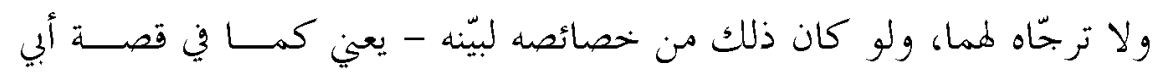

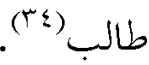

قال الحافظ: وما قاله أخيرًا هو الجواب، وما طالب به من البيان قد حَصَـلَ،

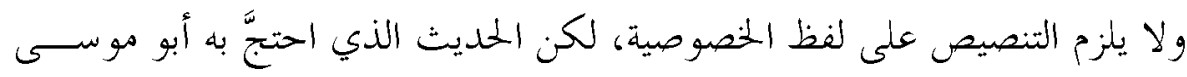

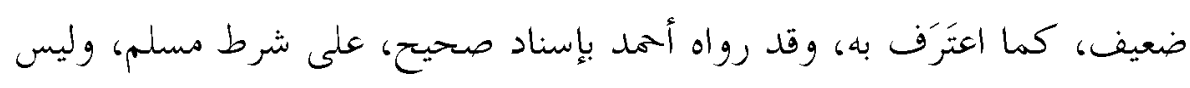

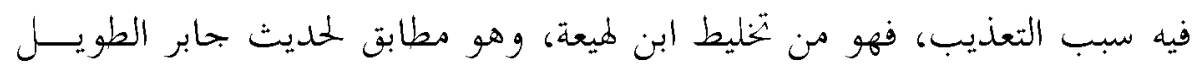

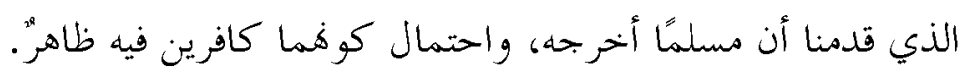

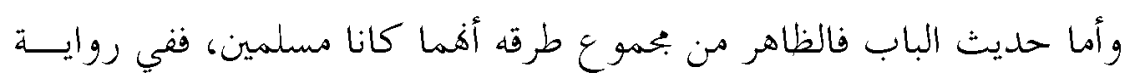

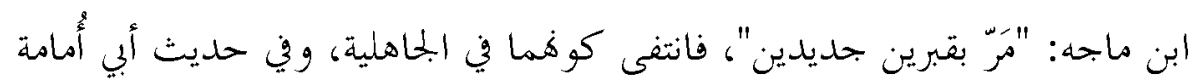

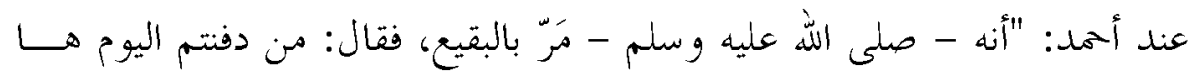

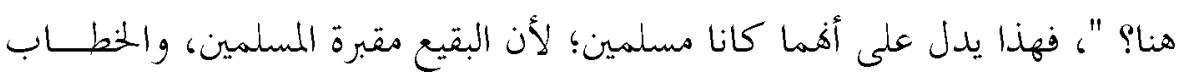

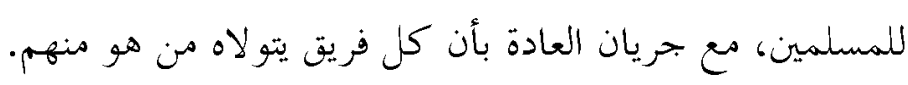

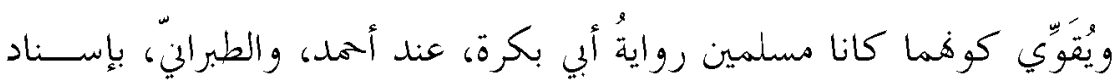
صحيح: "يعذبان، وما يُعَذَّبان في كبير، بلى ولى وما يعذبان إلا في الغيبة والبول". 


\section{فتح المنان في شرح الحديث : "..... إنهما يعذبان .... "دراسة حديثية تحليلية موضوعية -}

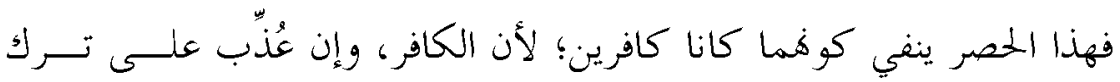
أحكام الإسلام، فإنه يعذب مع ذلك على الكفر بلا خحاف (ب0).

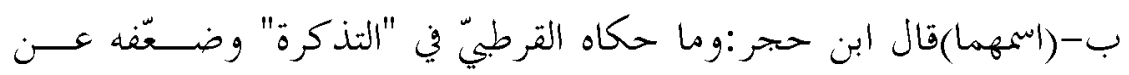
بعضهم أن أحدهما سعد ابن معاذ، فهو قول باطل لا ينبغي ذكره إلا مقرونًا ببيانه،

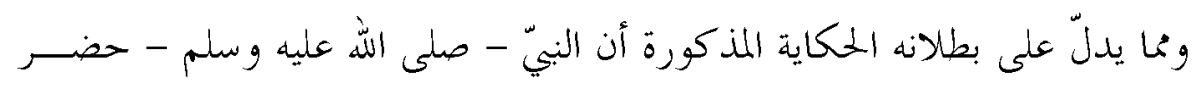

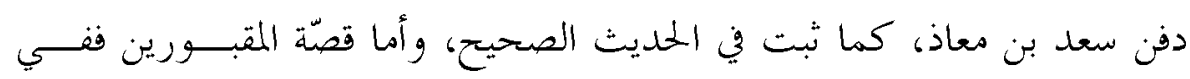
حديث أبي أمامة عند أحمد أنه - صلى الله عليه وسلم - قال لهم: "من دفنتم اليوم

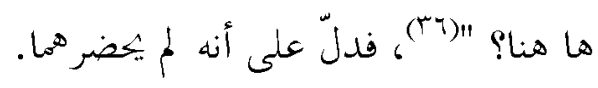

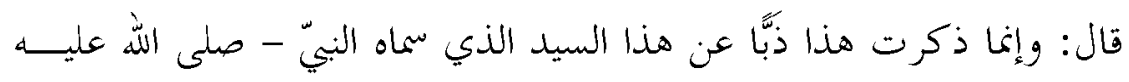

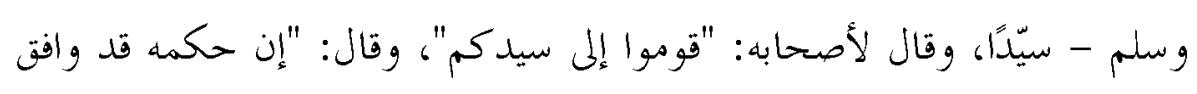

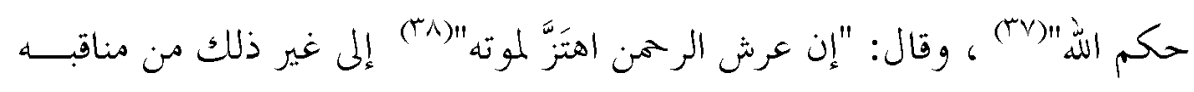

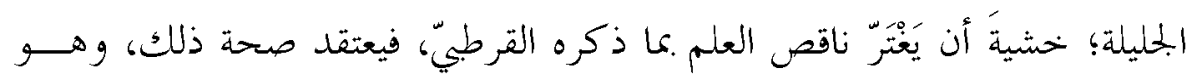

و لمُ يُعرف اسم المقبورين ولا أحدها، والظاهر أن ذلك كان على عَمْدَ مسـنـ

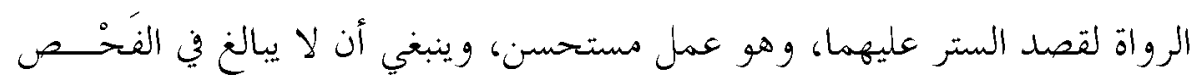
ry

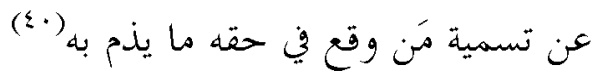

$$
\begin{aligned}
& \text { قوله :(أما هذا فكان لا يستنزه من بوله) }
\end{aligned}
$$

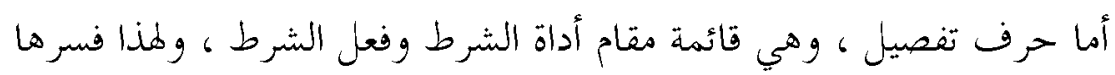

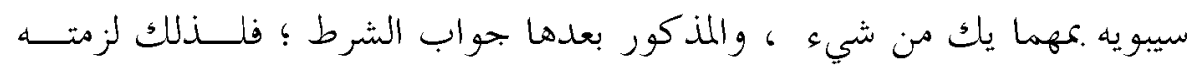
الفاء، نهو: أما زيد فمنطلق ، والأصل مهما يك من شيء فزئ فيد من منطلق ،فأنيبت أما

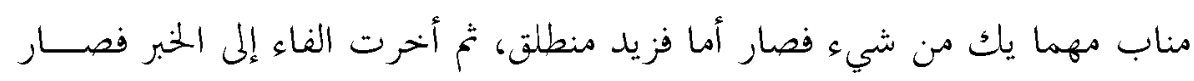

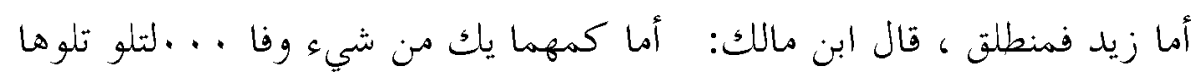

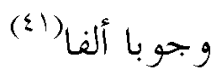


"هذا" إشارة إلى من في أحد القبرين "فكان لا يستتزه" بنون ساكنه بعـــها

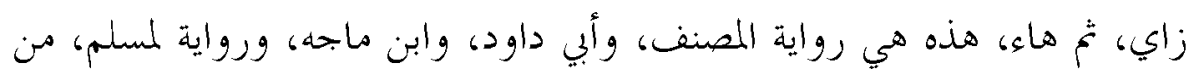

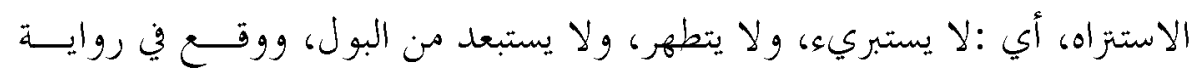

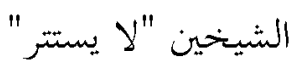

قال ابن حجر: كذا في أكثر الروايات معثناة من فوق الأولى مفتوحة والثانيــة مكسورة، وفي رواية ابن عساكر "يستبريء" .مو حدة ساكنة من الاستبراء. قال : فعلى رواية الأكثر معنى الاستتار أنه لا يجعل بينه وبين بوله سترة، يعسيني لا يتحفظ منه، فتوافق رواية "لا يستره" لأكا من التنزه وهو الإبعاد، وقد وقع عند

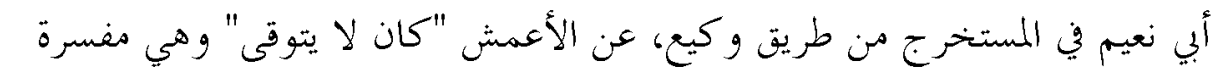

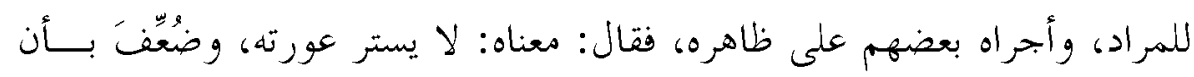

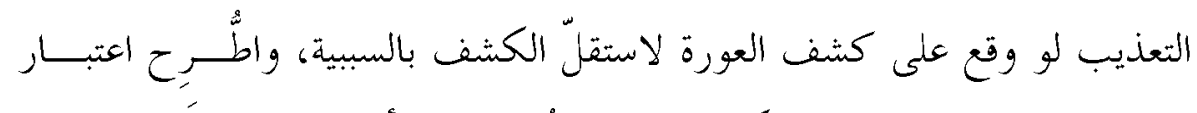
البول، فيترتب العذاب على الكشف، سواءو وُجدم البول أم لا، ولا يَخفىَى ما فيه.

$$
\text { وأما رواية الاستبراء، فهي أبلغ في التوقي. }
$$

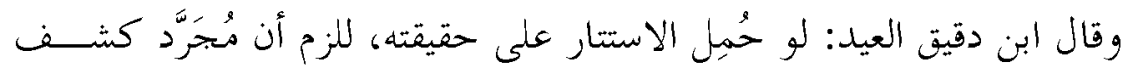

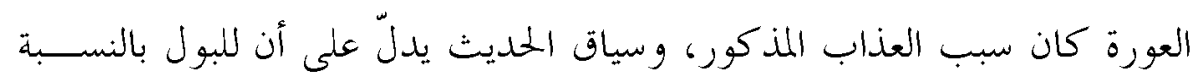

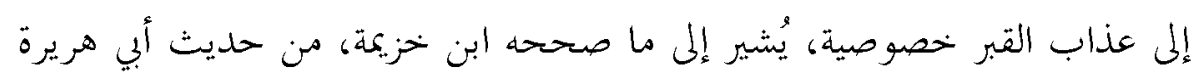

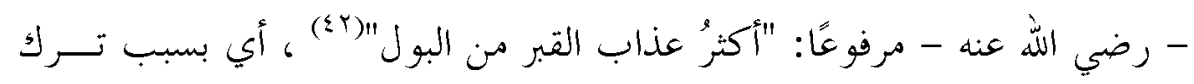

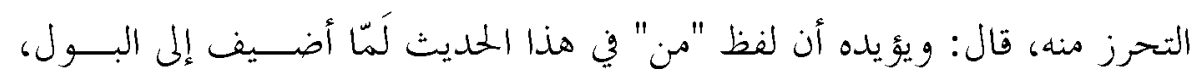

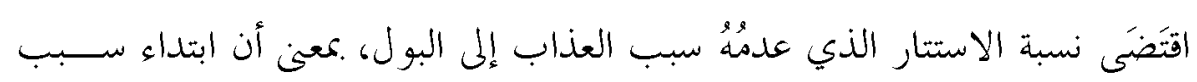

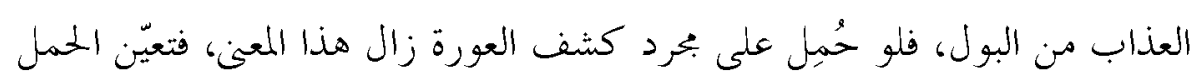

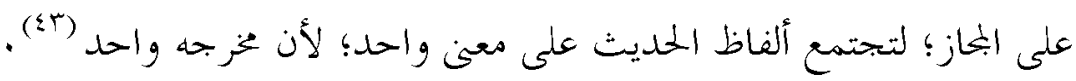

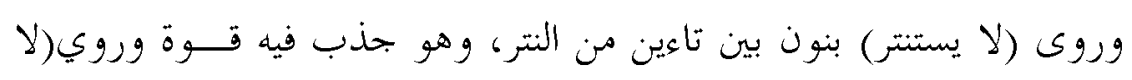
يستنث) بتاء مثناة من فوق مفتوحة ونون ساكنة و ثناء مثلثة مكسورة ، أي لا ينثر 


\section{فتح المنان في شرح الحديث : "..... إنهما يعذبان .... "دراسة حديثية تحليلية موضوعية -}

بوله من قناة الذكر كما ينثر الماءهن من أنفه بعد استنشاقه (§؟). قوله: (فكان يمشي بالنميمة )النميمة: نقل الحديث من قوم إلى قوم على جهة

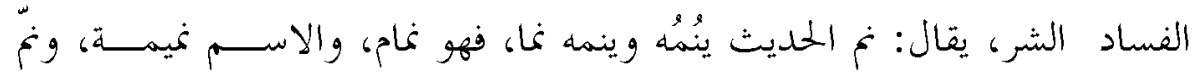

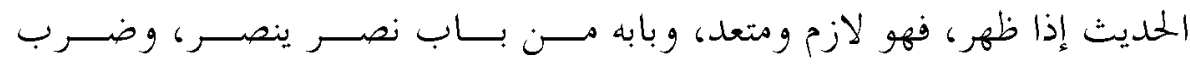
يضرب (so)

قوله: " ثم دعا بعسيب " أي: طلب عسيباً، والعسيب- بفتح العين وكســر

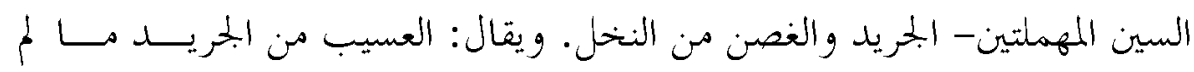
ينبت عليه الخوص، وما نبت عليه الخوص فهو السُفُْ.

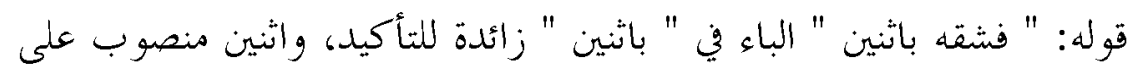
الحال، وزيادة الباء في الحال مشهورة. فئه بانين. قوله: " لعله يخغفف عنهما " الضمير في " لعله " راجع إلى العذاب،الــــي دل عليه قوله: " يعذبان "، وقد علم أن " لعل " حرف ينصب الاسم، ويرفع الخهـبر،

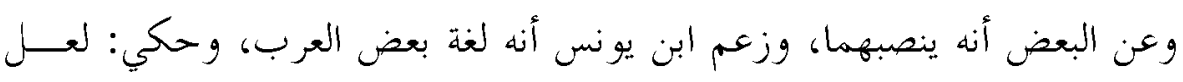

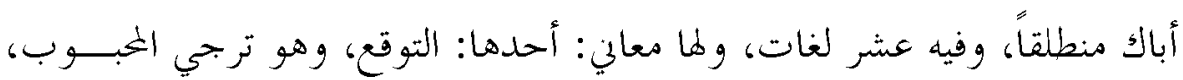
والإشفاق في الملكروه.

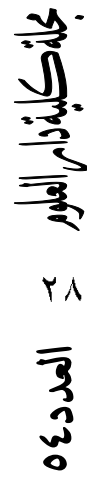

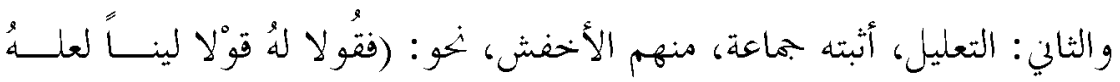
يتذكر) (تآ)، ومن لم يثبته يممله على الرجاء، أي: اذهبا على رجائكما. و الثالث:

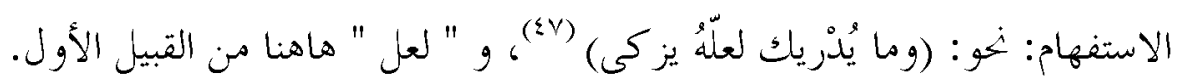

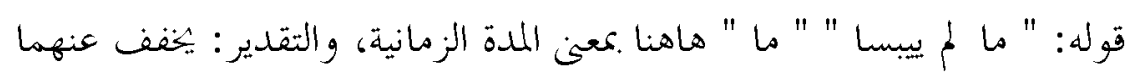
العذاب مدة عدم يُيس العسيب، أو يكون المعنى: يخفف عنهما العذاب في زمهـان عدم اليبس، و " ما لم يببسا " بفتح الباء الموحدة مثل السين، ويبوزز كسر البــاء

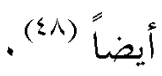




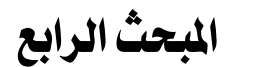 \\ قضايا الحديث}

- الأولى: إثبات عذاب القبر

لقد عني علماء الإسلام عناية كبيرة بالعقيدة الإسلامية ، خاصة ما كان منـــا

من قبيل السمعيات ،ومنها عذاب القبر ، حتى إنك لتجد البعض منهم خاصة أهل

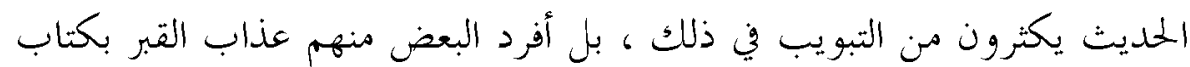

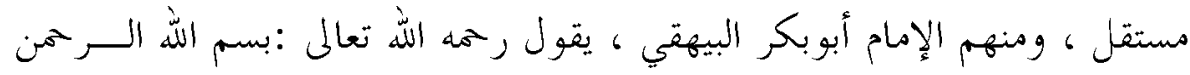

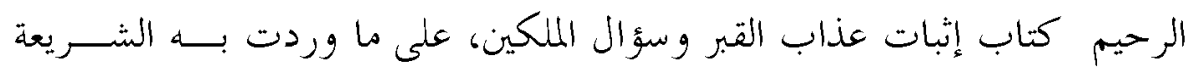

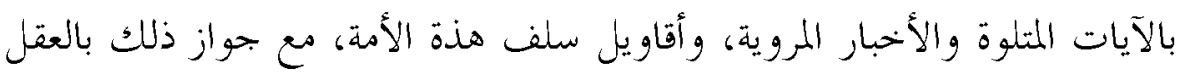
في قدرة الله سبحانه وتعالى كثم سرد فيه ثلاثين بابا تتوزع فيها الآيات والأحاديث

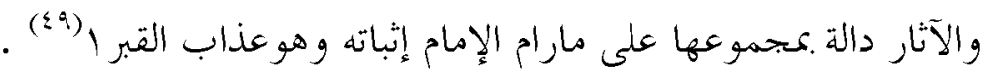

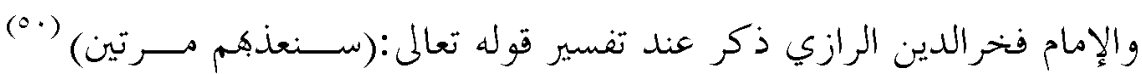

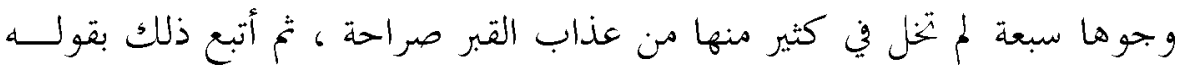

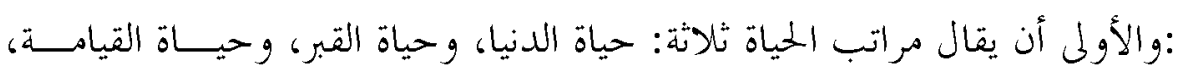
فتوله:سنعذهم مرتين المراد منه عذاب الدنيا بجميع أقساهه، وعذاب القبر. وقوله:

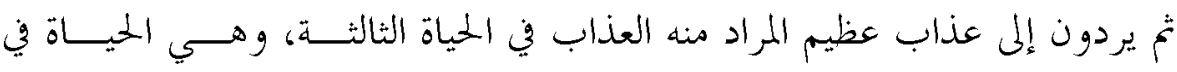
القيامة.

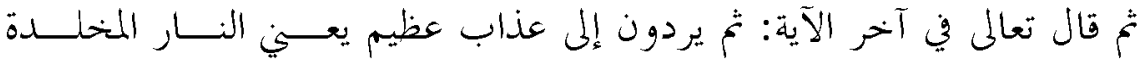
المؤبدة (0)

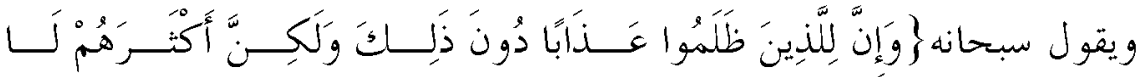

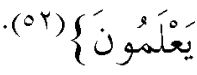
يروى ابن جرير الطبري عن قتادة، أن ابن عباسٍ كان يقول: إن عذاب القــبر

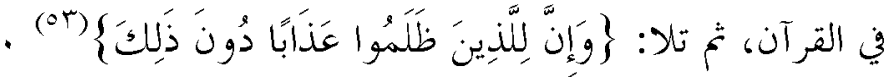




\section{فتح المنان في شرح الحديث : "..... إنهما يعذبان .... "دراسة حديثية تحليلية موضوعية -}

وغير ذلك كثير من آي الذكر الحكيم ·

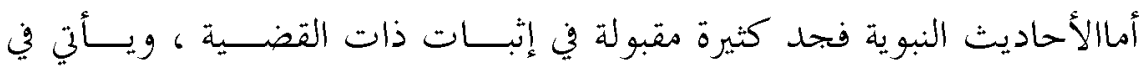
طليعتها حديث البحث ،و كذلك:

-ما رواه البخاري بسنده عن عائشة، رضي الله عنها، أن البني صلى الله عليــهـ

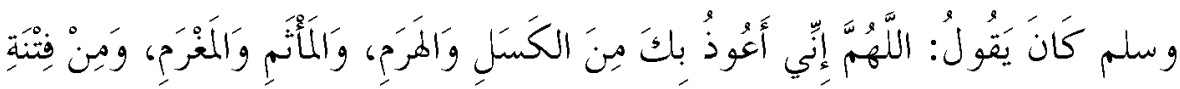

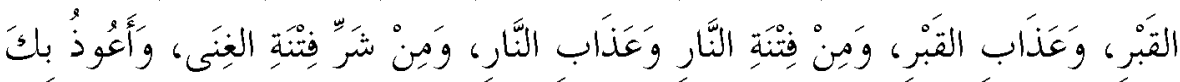

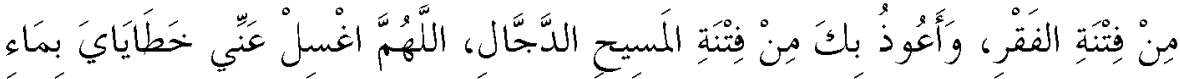

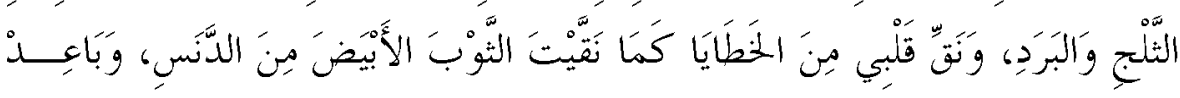

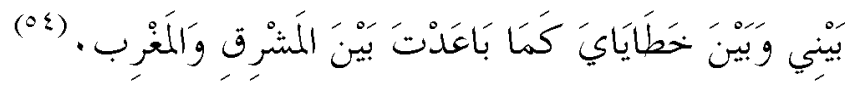

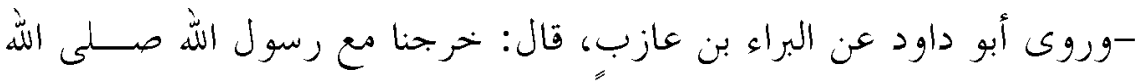

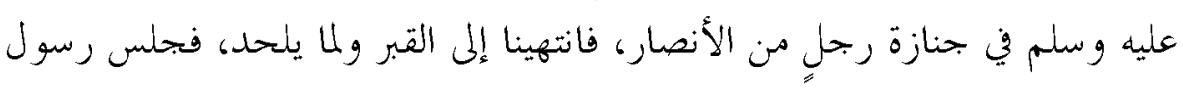

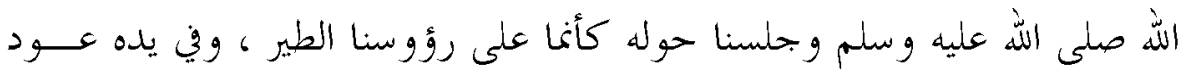
ينكت به في الأرض ، فرفع رأسه، فقال: استعيذوا بالله من عذاب القبر مرتين، أو روت وله

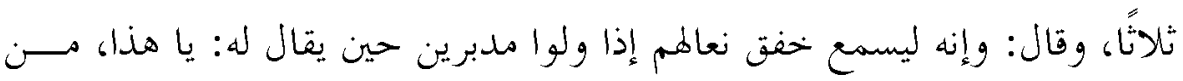

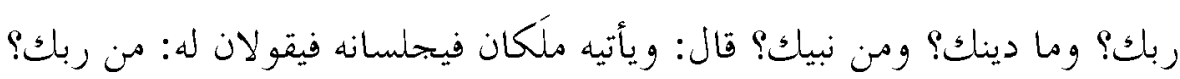
فيقول: ربي الله، فيقولان له: ما دينك؟ فيقول: ديني الإسلام، فيقولان له: ما هذا

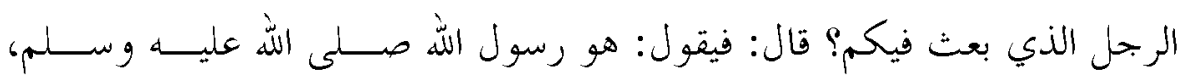
فيقولان: وما يدريك؟ ، فيقول: قرأت كتاب الله فآمنت به وصدقت، فذلك قول

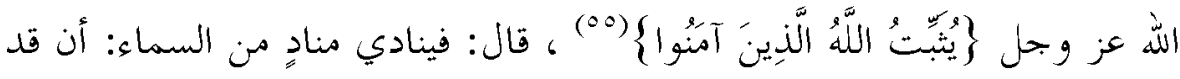

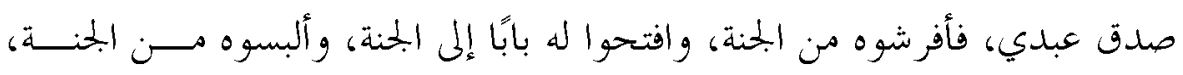

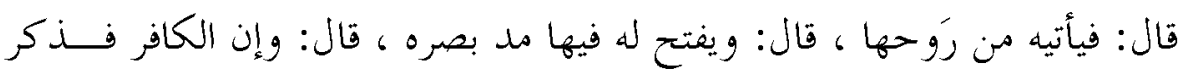

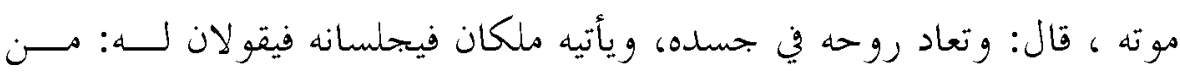
ربك؟ فيقول: هاه هاه هاه، لا أدري، فيقولان له: ما دينك؟ فيقول: هاه هاه ، لا 
أدري ، فيقو لان: ما هذا الرجل الذي بعث فيكم؟ فيقول: هــاه هـــاه، لا أدري، فينادي منادٍ من السماء: أن كذب، فأفرشوه من النار، وألبسوه من النار، وافتحوا

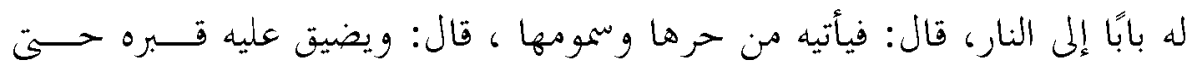

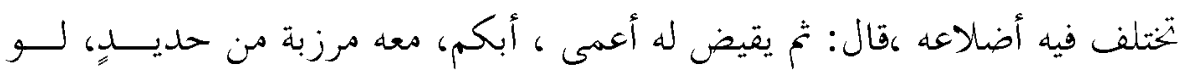

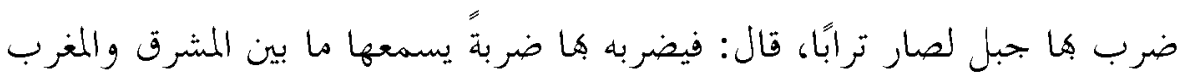

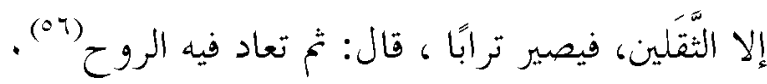

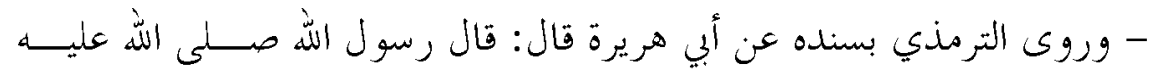

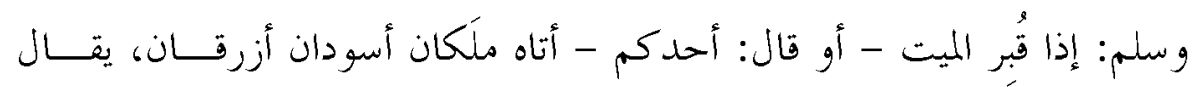

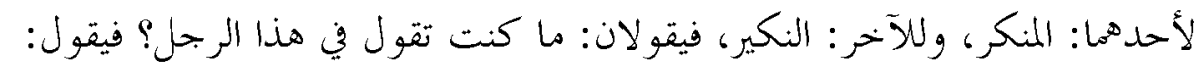

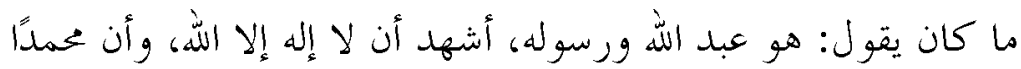
عبده ورسوله، فيقولان: قد كنا نعلم أناك تقول هذا، ثم يفسح لــهـه في قـبره

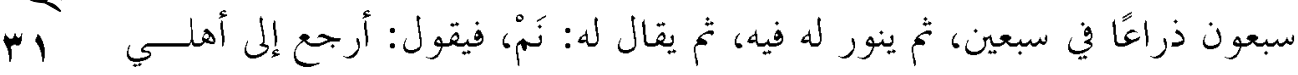

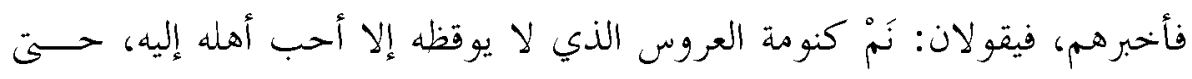

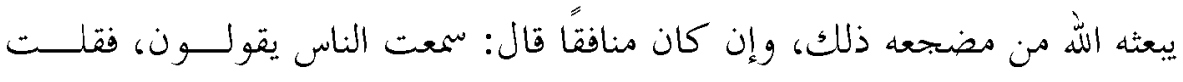
مثله، لا أدري، فيقولان: قد كنا نعلم أنك تقول ذلك، فيقال لــالَّرض: التئمسـي

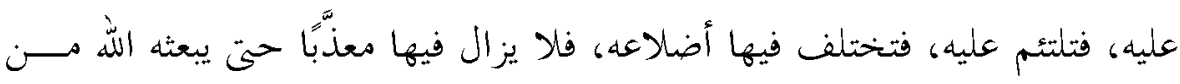
مضجعه ذلك. (ov)

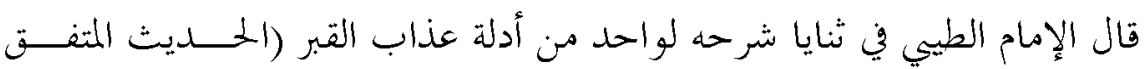

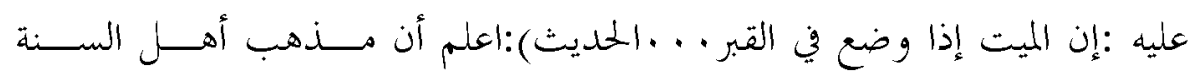
والجماعة إثبات عذاب القبر، وقد تظاهرت عليه الدلائل من الكتاب والسنة، قال

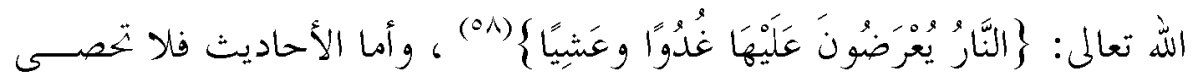
كثرة، ولا مانع في العقل أن يخلق الله تعالى الحيوة في جزء من الجسد أو في جميعه

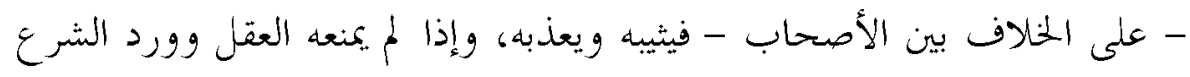




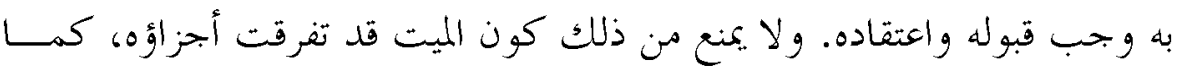
يشاهد في العادة، أو أكلته السباع والطيور وحيتان البحر، كما أن الله تعالى يعيده

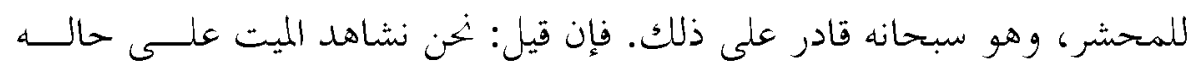
فكيف يسأل، ويقعد، ويضرب، ولا يظهر أتر؟ فالجواب: أن ذلك غير مُتنع بل له له

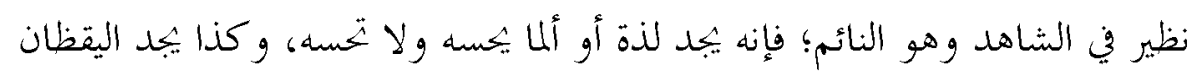

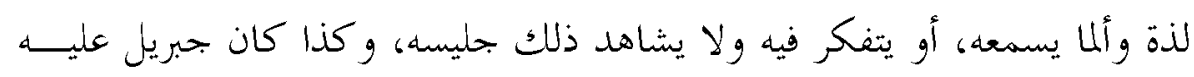

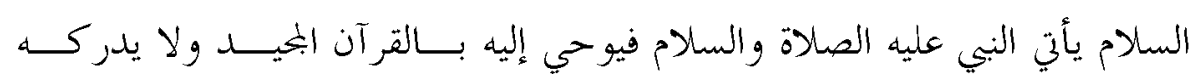
الحاضرون، وكل ذلك دليل ظاهر جلي. وقال :من مات وتفرقت أجزاؤه في الشرق والغرب، فإن الله تعالى يعلق روحهد

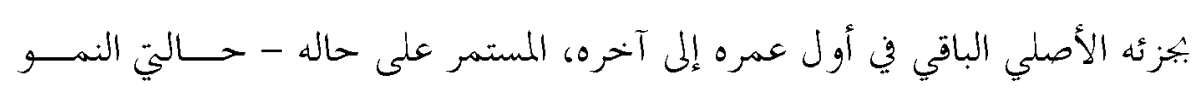

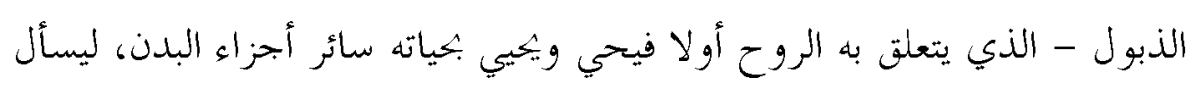

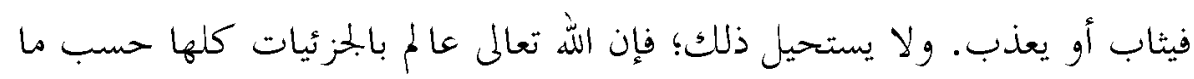

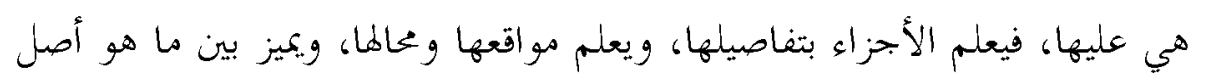

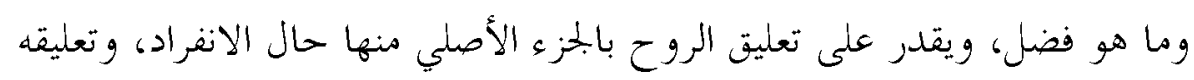

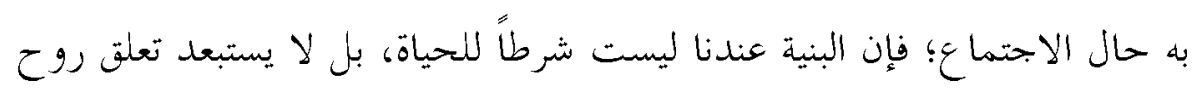

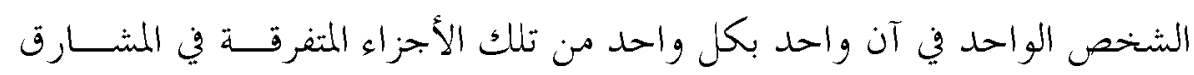
والمغارب؛ فإن تعلقه ليس على سبيل الحلول حتى يمنعه الحلول في جزء من الحلول

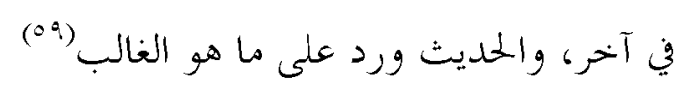

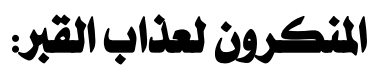

المنكرون لعذاب القبر ونعيمه وسؤال الملكين هم: الخوارج، والجهميــة، ومعظــم

$$
\text { (7.) المعتزلة }
$$

ومن شبهرم أن قالوا: إنا نكشف القبر؛

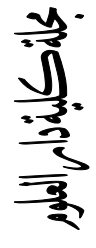

rY

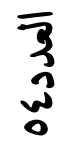


فلا بند فيه ملائكة يضر بون الموتى، ولا حيات، ولا تعابين، ولا نــيران تــأججا!

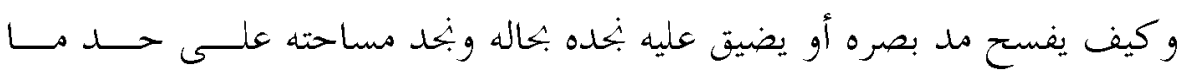
حفرناه له يزد ينقص؟! وكيف يصير القبر روضة من رياض الجنة أو حفــرة مــن

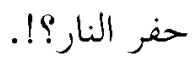
والجواب :أن حال البرزخ من الغيوب التي أخبرت ها الأنبياء، ولا يكون خهـبرهم مالاً في العقول أصلاً؛ فلا بد من تصديق خحبرهم.

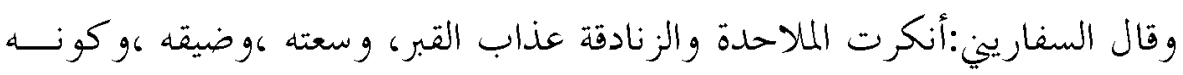
حفرة من حفر النار كأو روضة من رياض المنة كوأنكروا جلوس الميت في قــبره،

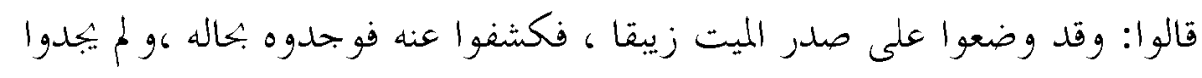

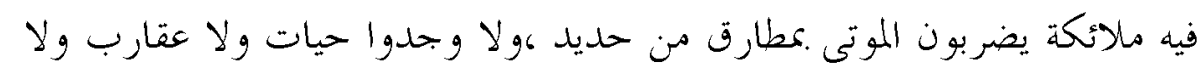

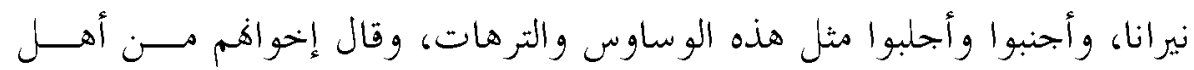
البدع والضلال :كل حديث يخالف مقتضى العقول نقطع بتخطئة ناقلــه، قــالوا

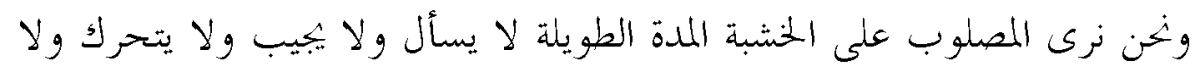

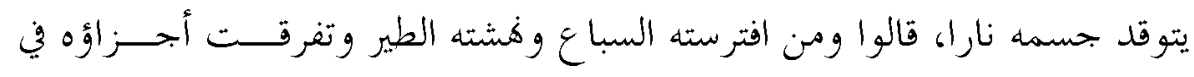

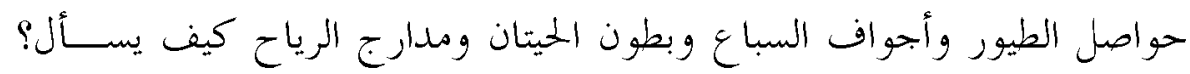
و كيف يصير القبر على مثل هذا روضة أو حفرة؟ و كيف يتسع قبره أو يضــيق؟ وتئ وأكثروا من هذا الهذيان. (T) تخ قال نقلا عن غيره: إن الرسل عليهم الصلاة والسلام لم تخبر بما تحيله العقول بل هل

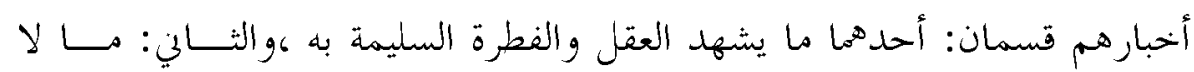
تدركه العقول .كمجردها ، كالغيوب التي أخبروا ها عن تفاصيل البرزخ واليوم الآخر

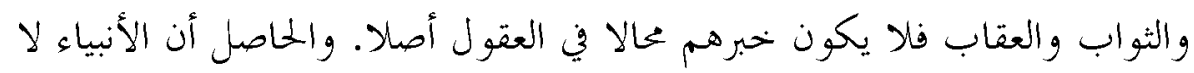

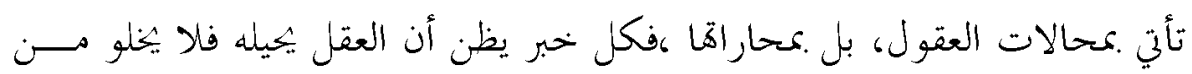
أحد أمرين :إما خطأ في النقل أو فساد في العقل ،فتكون شبهة خيالية ظن صاحبها 


\section{فتح المنان في شرح الحديث : "..... إنهما يعذبان .... "دراسة حديثية تحليلية موضوعية -}

أذا أمر عقلي صريح ،والحال أنه خيال وهمي غير صحيح، قال تعـالى أويـــى

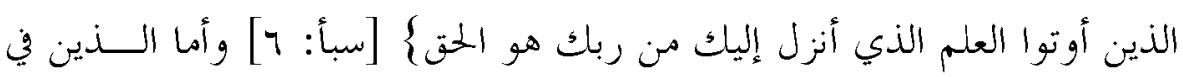
قلو كهم زيغ فلا يزدادون إلا رجسا على رجسهم.

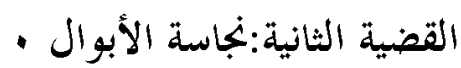

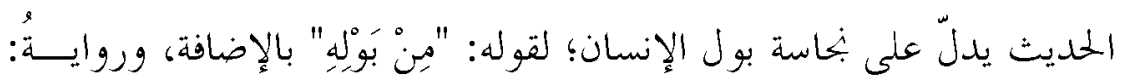

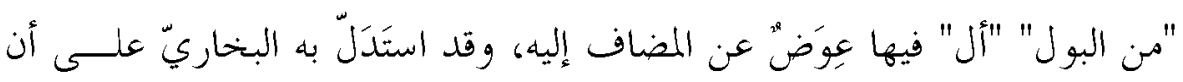

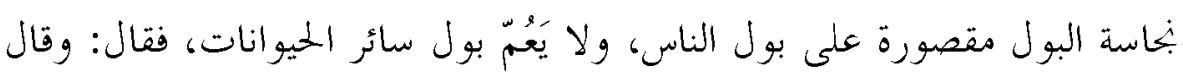

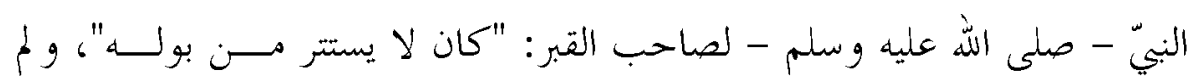

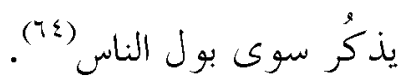
قال ابن بطّل : أراد البخاريّ أن المراد بقوله - صلى الله عليه وسلم - " "كان

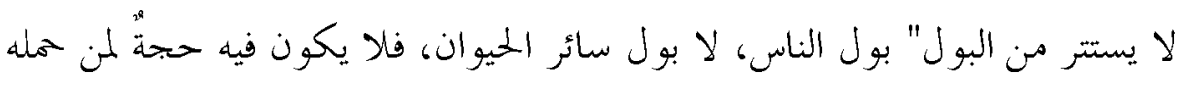

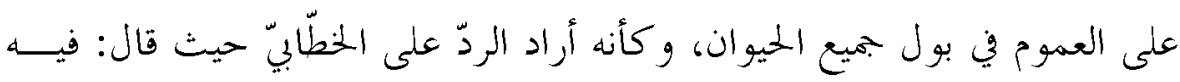

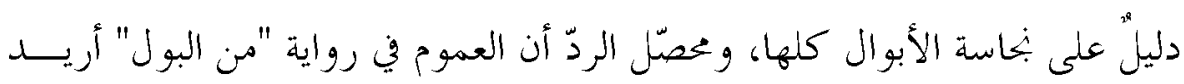

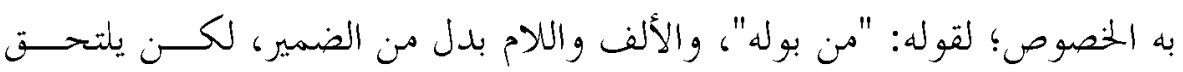

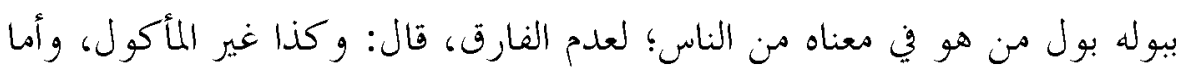
المأكول فلا حجة في هذا الحديث لمن قال بنجاسة بوله، ولمن قال بطهارته حُجج أخرى (10)

$$
\text { وقال الشو كاني : }
$$

والظاهر طهارة الأبوال والأزبال من كل حيوان يؤ كل لحمه تمسكا بالأصل، واستصحابا للبراءة الأصلية، والنجاسة حكم شرعي ناقل عن الحهم الذي يقتضيه

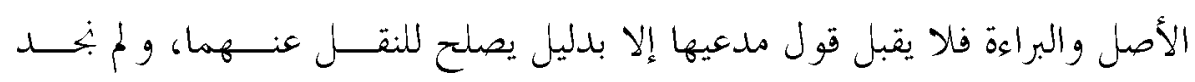

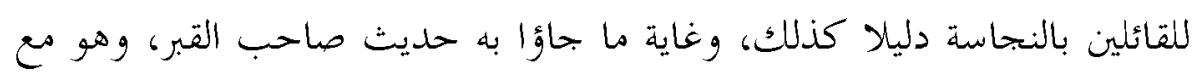




\section{فتح المنان في شرح الحديث :".... إنهما يعدبان ...."دراسة حديثية تحليلية موضوعية}

كو نه مرادا به الخصوص كما سلف عموم ظي الدلالة لا ينهض علسى معارضسـة تلك الأدلة المعتضدة بما سلف.

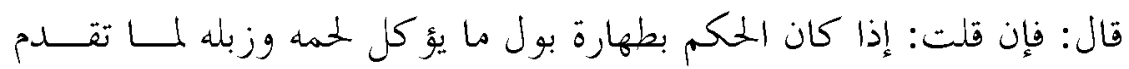
حتى يرد دليل فما الدليل على بناسة بول غير المأكول وزبله على العمو م. قلت: قد تمسكوا بكديث "إها ركس" قاله - صلى الله عليــهـ وســلم - في الروثة أخرجه البخاري والترمذي والنسائي، و.ما تقدم في بول الآدمـي وألحةــــوا

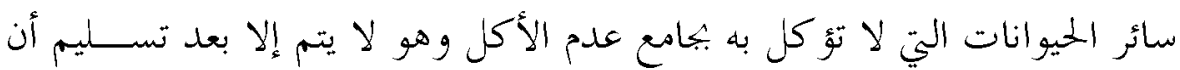
علة النجاسة عدم الأكل، وهو منتقض بالقول بنجاسة زبل الجحلالة، والدفع بــأن

وأما الاستدلال كفهوم حديث "لا بأس ببول ما يؤكل لحمه" فنسير صـالخ

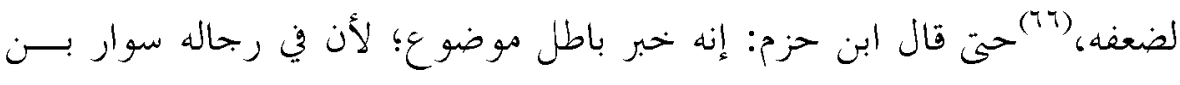

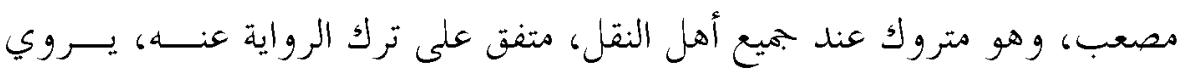

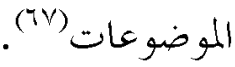
فالذي يتحتم القول به في الأبوال والأزبال هو الاقتصار على بناســة بــول

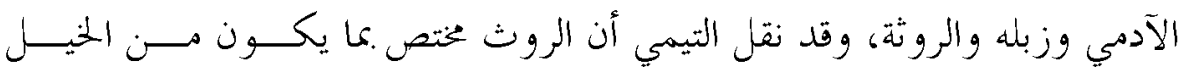
والبغال والحمير ولكنه زاد ابن خزيمة في روايته "إفا ركس إفا روثة حمار".

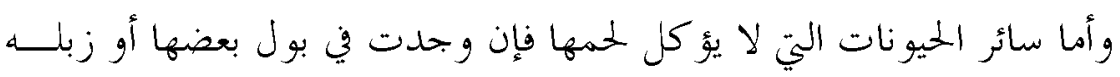

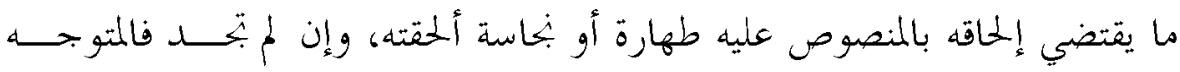

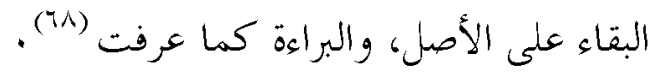




\section{فتح المنان في شرح الحديث : "..... إنهما يعذبان .... "دراسة حديثية تحليلية موضوعية -}

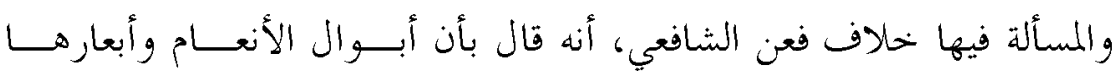
نجسة (79)

وهذا القول -أي: بالنجاسة- هو مذهب أبي حنيفة ، والشافعي ، وهو رواية

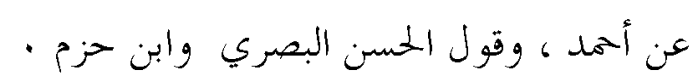

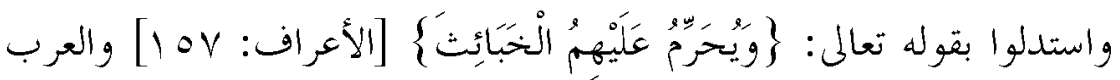
تستخبث هذا -

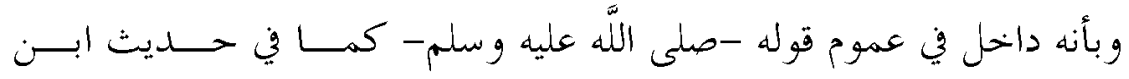
عباس: "تنزهوا من البول" . ولأنه رجيع، فكان نجسًا كرجيع الآدمي.

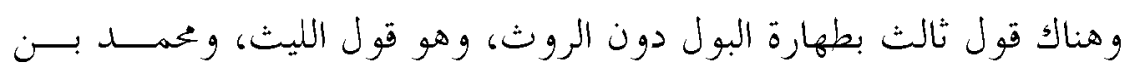

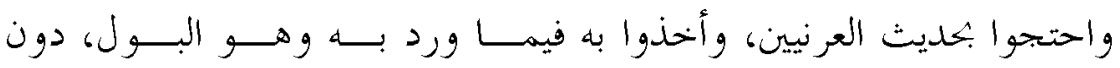

قلت:وهذا الذي قاله الشوكاني من ترجيح القول الأول هوالراجح عنـــي ،

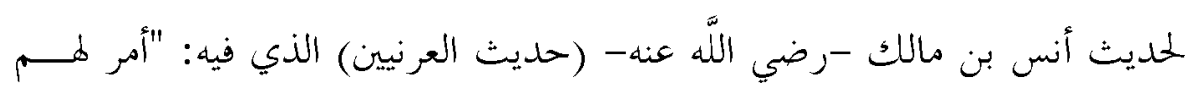

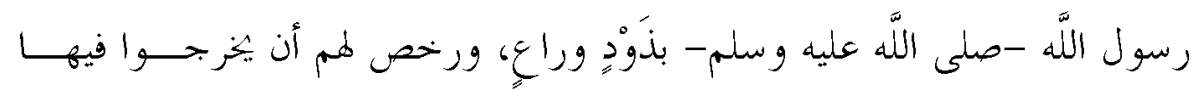

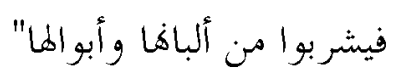
• وجه الدلالة: أن النبي -صلى اللَّه عليه وسلم- أمرهم بأن يشربوا من أبوال

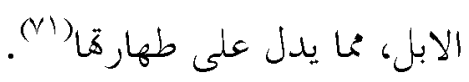

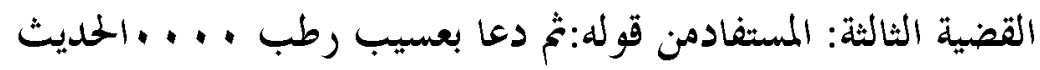

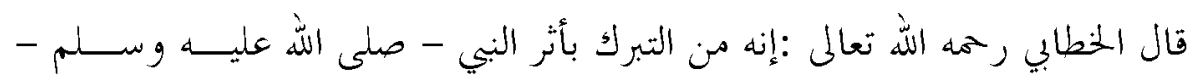

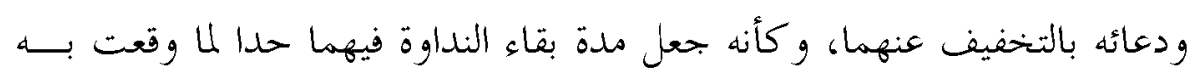

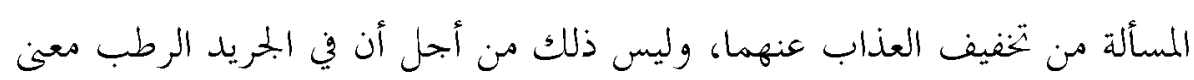




\section{فتح المنان في شرح الحديث :".... إنهما يعذبان ...."دراسة حديثية تحليلية موضوعية}

ليس في اليابس، والعامة في كثير من البلدان تغرس الخـــوص في قبــور موتــــمه،

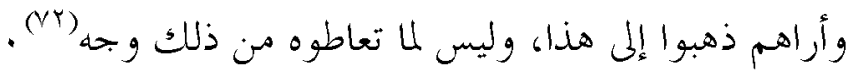

وقال الشيخ أحمد شاكر:

وصدق الخطابي، وقد ازداد العامة إصرارا على هذا العمل الذي لا أصل له، وغلوا فيه

بينما استدل به بعضهم على استحباب وضع الجريد الأخضر على القبور، ويطرد

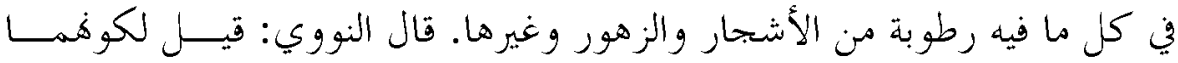
يسبحان ماداما رطبين. وليس لليابس تسبيح. وهذا مذهب كثيرين أو الأكثــــين من المفسرين في قوله تعالى: \}وإن من شيء إلا يسبح بحمده

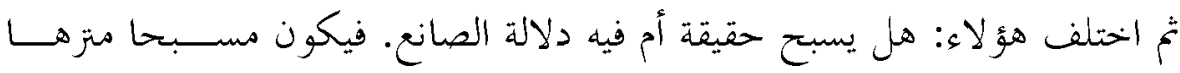

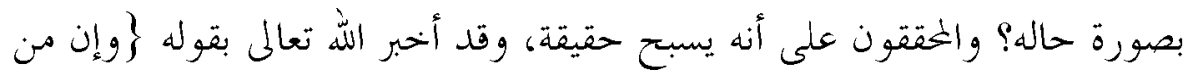

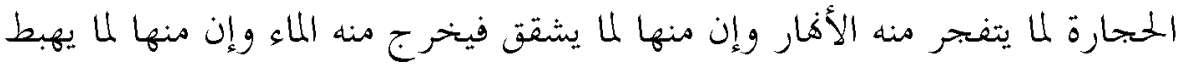

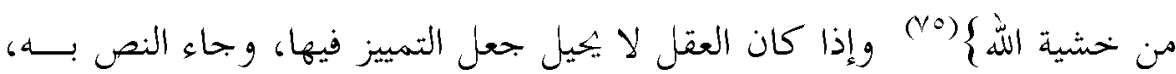
وجب المصير إليه (v).

قال الشافعية والحنابلة والحنفية: ويسن وضع الجريد الأخضر والريحان ونهوه مــن

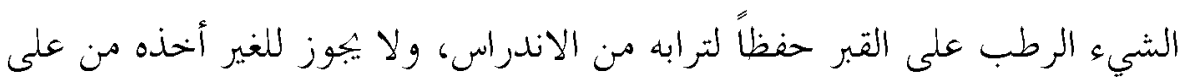
القبر قبل يبسه؛ لأن صاحبه لم يعرض عنه إلا عند يبسه، لزوال نفعه الذي كان فيه وقت رطو بته، وهو الاستغفار. و يكره قطع النبات الرطب والحشيش من المقبرة، دون اليابس؛ لأنه مادام رطبــأ

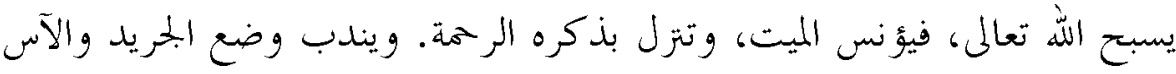
ونهو هما على القبور . والدليل: ما ورد في الحديث الصحيح من وضعه عليه الصلاة 


\section{فتح المنان في شرح الحديث : "..... إنها يعذبان .... "دراسة حديثية تحليلية موضوعية -}

والسلام الجريدة الخضراء، بعد شقها نصفين على القبرين اللذين يعذبان، وتعليلــه

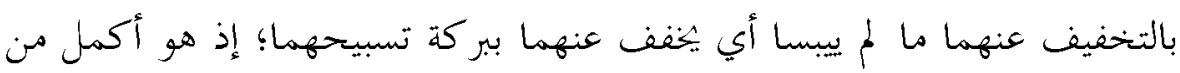
نسبيح اليابس، لما في الأخضر من نوع حياة. فكراهة قطع ذلك وإن نبت بنفسه، للا فيه من تفويت حق الميت.

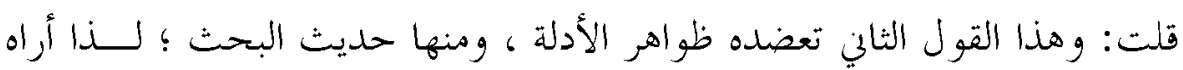

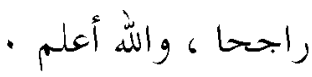
وصلى الله وسلم و بارك على سيدنا ونبينا و حبيبنا محمد وعلى آله وصحبه وسلم

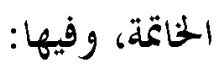

أ-النتائج:وبعد تطو اف تحليلي موضوعي وتناول لهذا الحســديث توصــلت إلى 1- محورية السنة النبوية في التأسيس لأدق مسائل العقيدة الإسلامية.

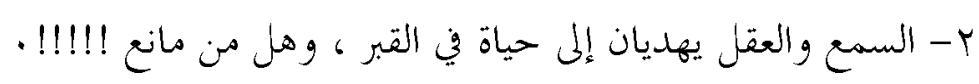
r- جوهرية دورالسنة في التأسيس لعديد الأحكام الشرعية . ع - حرص رسول اللّ صلى اللّ عليه وسلم أمته في حياتم ومثاتهم . لاتزال السنة بحاجة إلى مزيد من جهود وعناية الأمة.

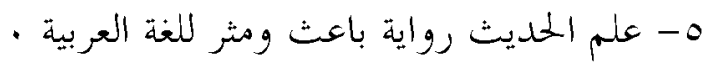

7- لعلمائنا فضل كبير في تذليل استفادتنا بالسنة تحليليا وموضوعيا. ب- أهم المصادر والمراجع :

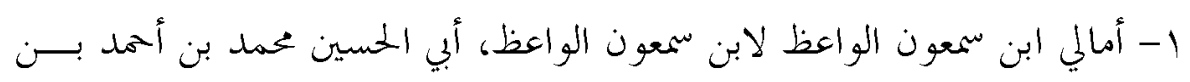
إسماعيل بن عنبس البغدادي (المتوف:

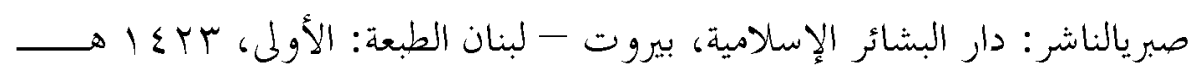




\section{فتح المنان في شرح الحديث :".... إنهما يعذبان ...."دراسة حديثية تحليلية موضوعية}

r- البحر الخيط الثجاج في شرح صحيح الإمام مسلم بن الحجاج المؤلف: محمد بن علي بن آدم بن موسى الإتيوبي الولوي الناشر: دار ابن الجوزي الطبعة: الأولى، $(\rightarrow 1 \leq r q-1 \leqslant r q)$

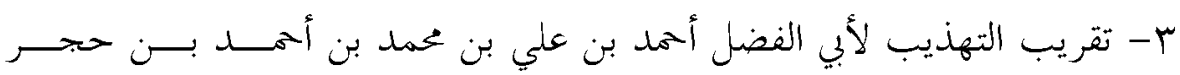

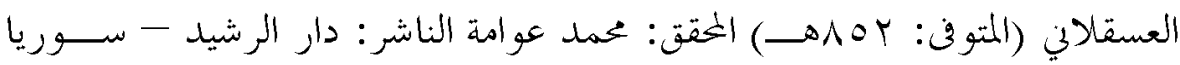

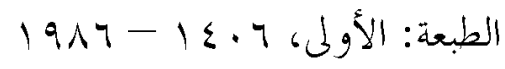

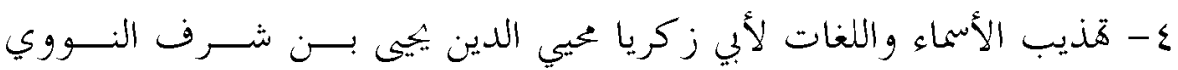

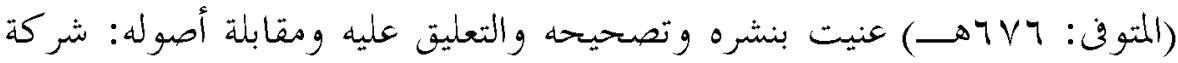

العلماء.مساعدة إدارة الطباعة المنيرية طبعة: دار الكتب العلمية، بيروت - لبنان

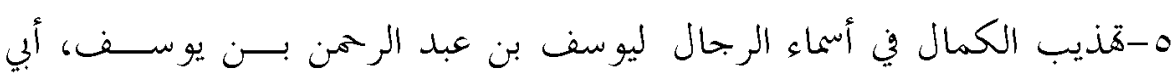

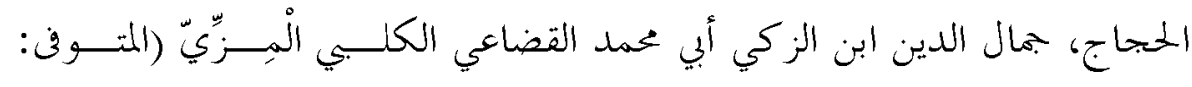

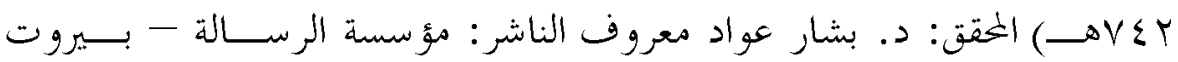

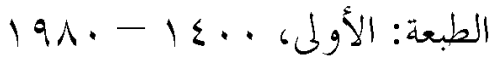

4- جامع البيان في تأويل القرآن لخمدا بن جرير بن يزيد بن كـثير بــن غالــبـ

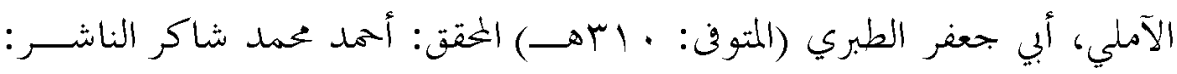

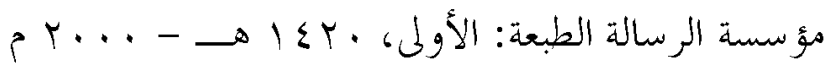

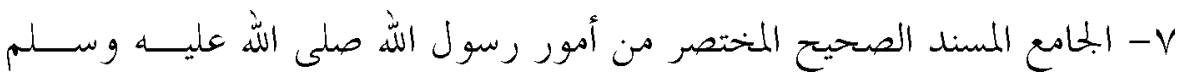

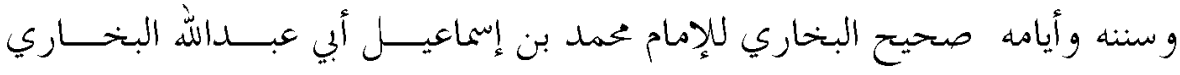
الجعفي الخقق: محمد زهير بن ناصر الناصر الناشر: دار طوق النجاة (مصورة عن

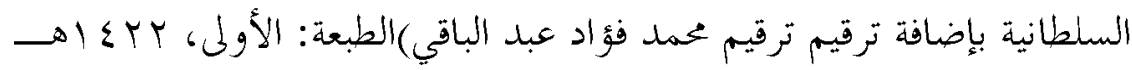
1- ديوان الإسلام لشمس الدين أبي المعالي محمد بن عبد الـــرحمن بـــن الغــزي

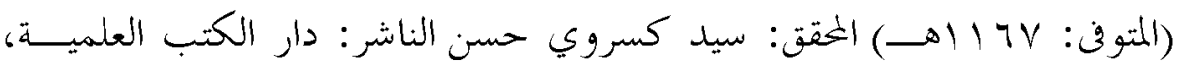

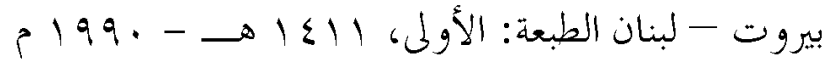




\section{فتح المنان في شرح الحديث : "..... إنهما يعذبان .... "دراسة حديثية تحليلية موضوعية -}

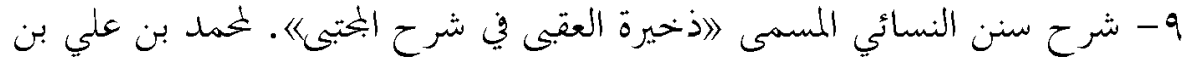

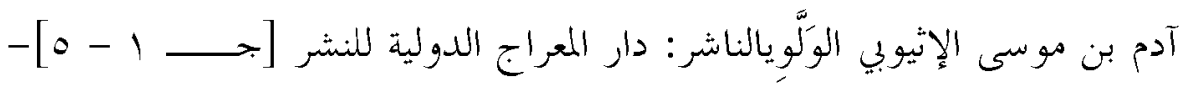

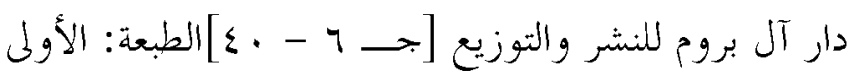
• ا- السنن الكبرى لأبي عبد الرحمن أحمد بن شعيب بن علي الخراساتي، النسائي (المتوفى: ب. بهــ) حققه وخرج أحاديثه: حسن عبد المنعم شبي أشرف عليــه: شعيب الأرناؤوط قدم له: عبد الله بن عبد الخسن التركي الناشر: مؤسسة الرسالة

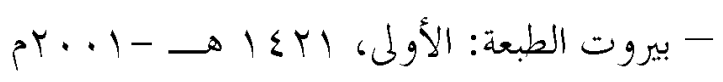

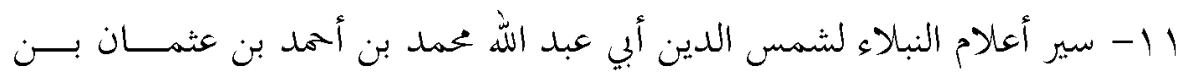

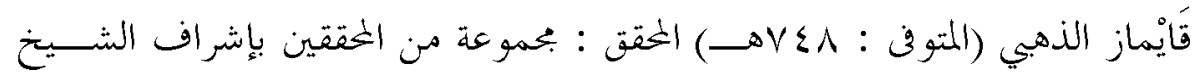

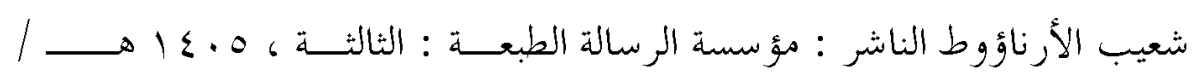
< 1910 r ا - شرح ابن عقيل على ألفية ابن مالك لابن عقيل ، عبد الله بن عبد الــرحمن

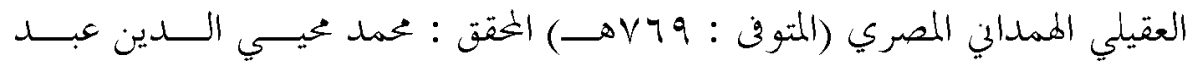
\&. الحميد الناشر : دار التراث - القاهرة، دار مصر للطباعة ، سعيد جودة الســار

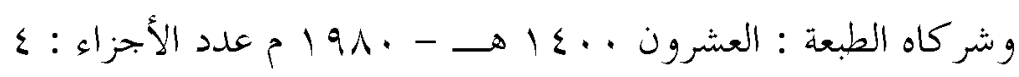
$\overline{3}$
3
0

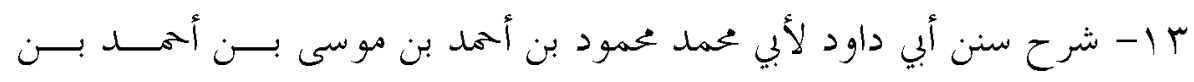

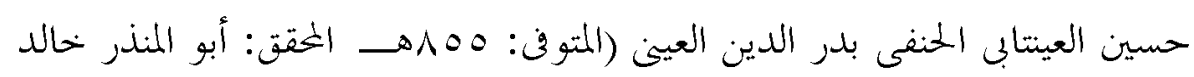

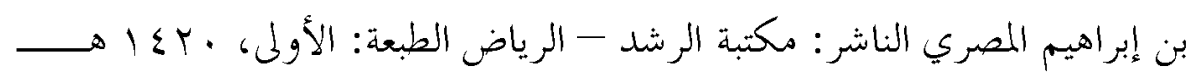
? $1999-$ ع ا- الشريعة لأبي بكر محمد بن الحسين بن عبد الله الآجُرِيُّ البغدادي (المتـــوفي:

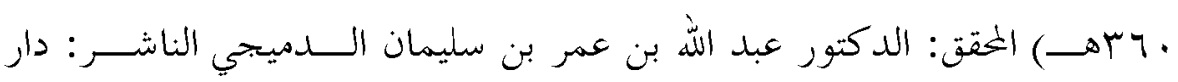

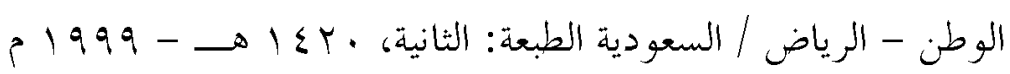




\section{فتح المنان في شرح الحديث :".... إنهما يعذبان ...."دراسة حديثية تحليلية موضوعية}

هـ-شَوَاهِد التَّوضيح وَالتَّصحيح لمشكلات الجلامع الصَّحيح لمحمد بن عبد الله، ابن

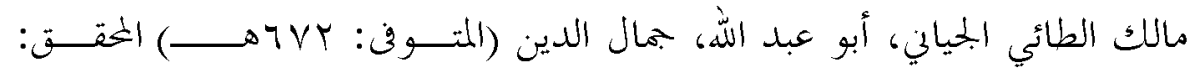

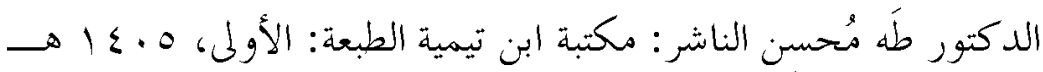

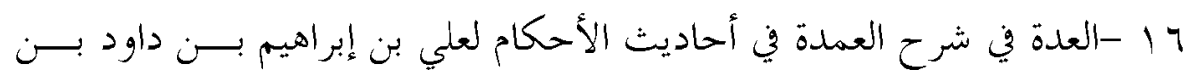

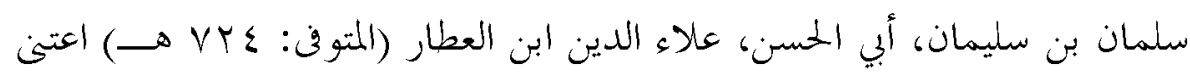

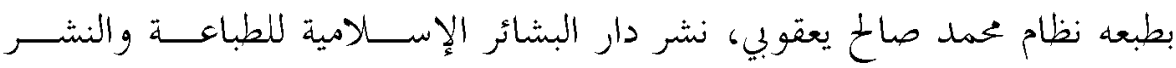

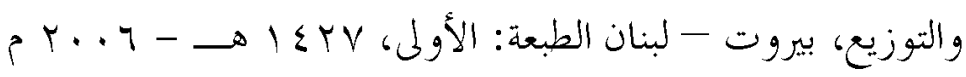

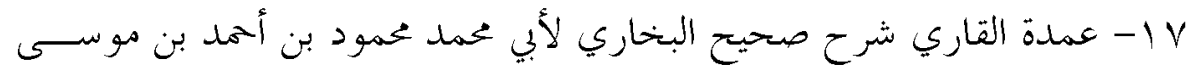

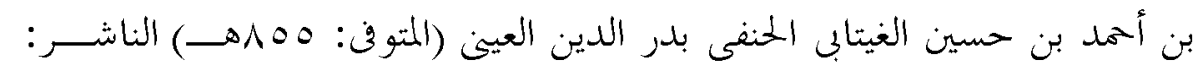
دار إحياء التراث العربي - بيروت 1 ا- عون المعبود شرح سنن أبي داود، ومعه حاشية ابن القيم: تذذيب ســـن أبي داود وإيضاح علله ومشكاله لمحمد أشرف بن أمير بن علي بن حيدر، أبي عبــد

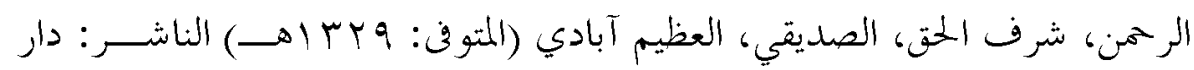

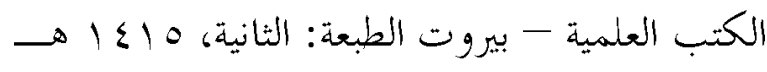

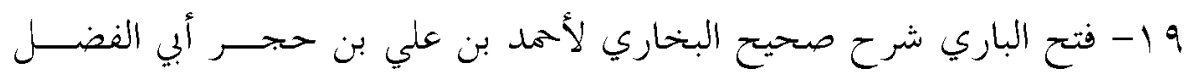

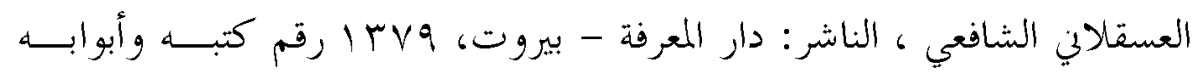
وأحاديثه: محمد فؤاد عبد الباقي قام بإخراجه وصححه وأشرف على طبعه: محب رئه الدين اللططيب عليه تعليقات العلامة: عبد العزيز بن عبد الله بن باز

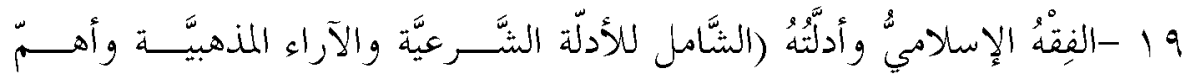

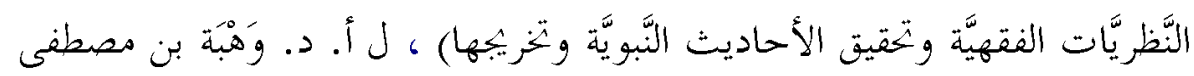
الزُحَيْليّ، الناشر: دار الفكر - سوريَّة - دمشت الطبعة: الرَّابعة .

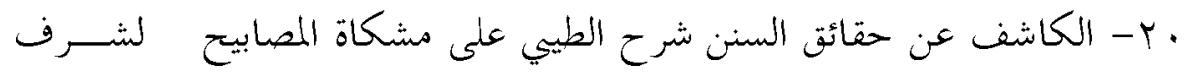

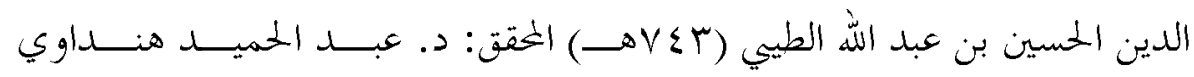




\section{فتح المنان في شرح الحديث : "..... إنهما يعذبان .... "دراسة حديثية تحليلية موضوعية -}

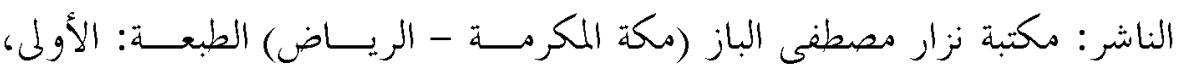
₹199V- $\rightarrow 1 \leq 1 \mathrm{~V}$

ا ا-Y-اللطائف في اللغة = معجم أسماء الأشياء لأحمد بــن مصـــفى اللَّبابيــــي الدمشقي (المتوفى: ^ماب اهــ) الناشر: دار الفضيلة - القاهرة

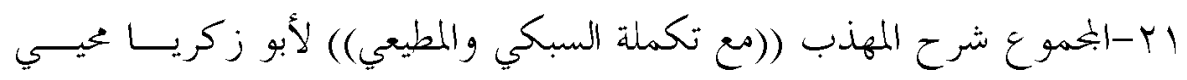

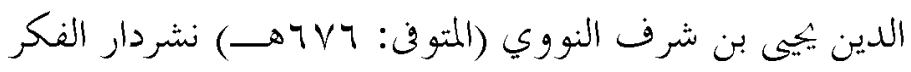

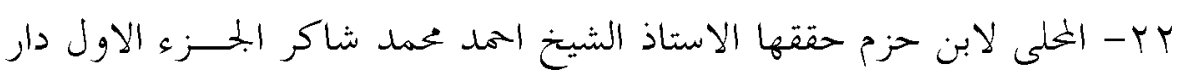
الفكر بr- مختصر الأحكام = مستخرج الطوسي على جامع الترمذي لأَّبي عَلِّيّ الحسنُ

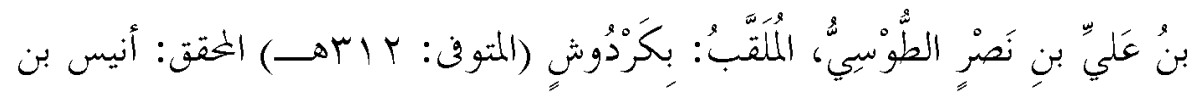

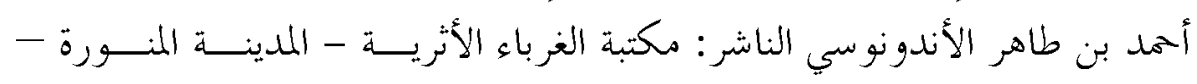

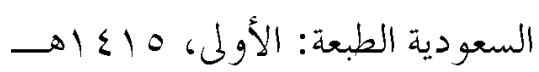
牙 ع - مسند الإمام أحمد بن حنبل لأبي عبد اللّ أحمد بن محمد بن حنبل بن هــلال

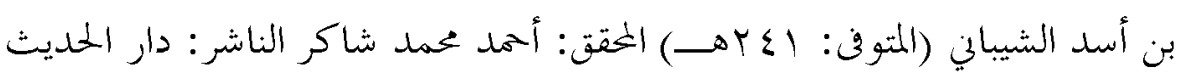

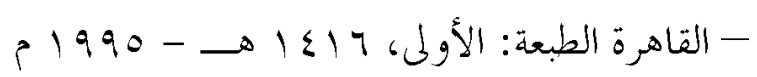
$\leqslant Y$ $\overline{3}$ هو-المسند للإمام أحمد بن حنبل أبي عبدالله الشيباني الناشر: مؤسسة قرطبــة القاهرةالأحاديث مذيلة بأحكام شعيب الأرنؤوط عليها

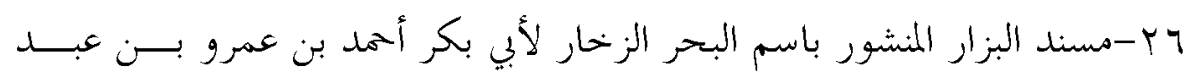

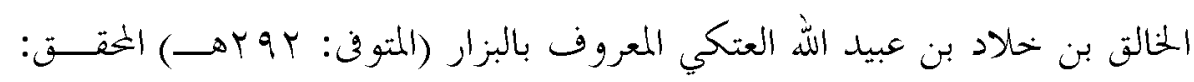

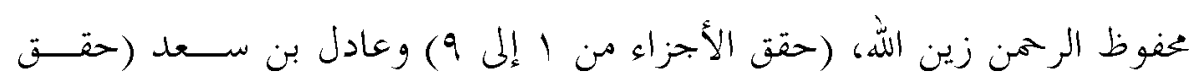

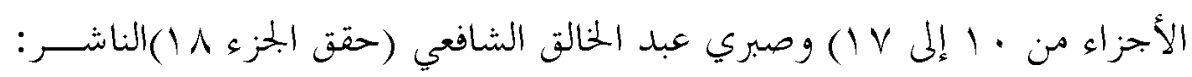

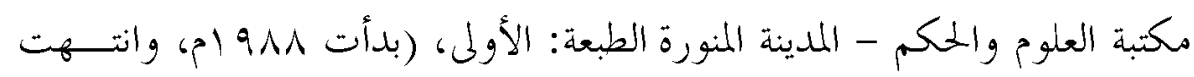

$$
\left(p^{Y} \cdot q^{\prime}\right.
$$




\section{فتح المنان في شرح الحديث :".... إنهما يعذبان ...."دراسة حديثية تحليلية موضوعية}

V V - المصباح المنير في غريب الشرح الكبير لأحمد بن محمد بن علي الفيـومي ثم

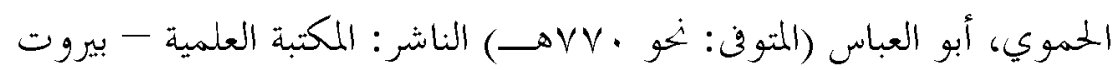

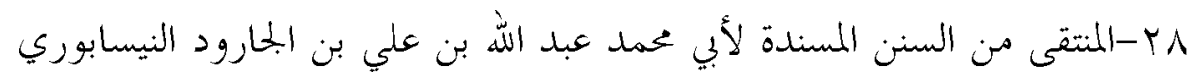

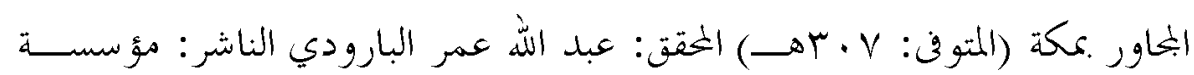

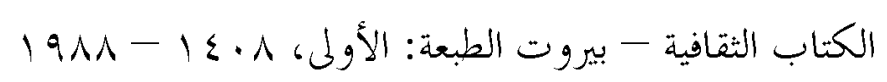

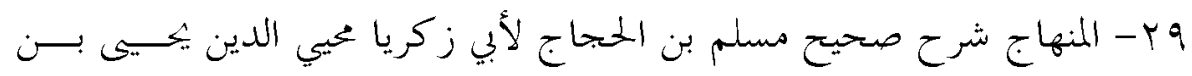

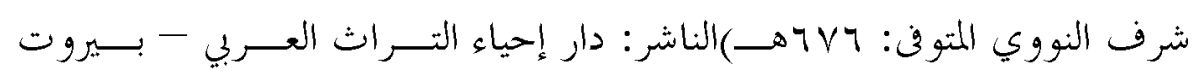

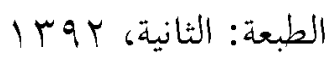

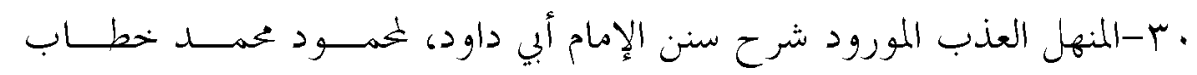

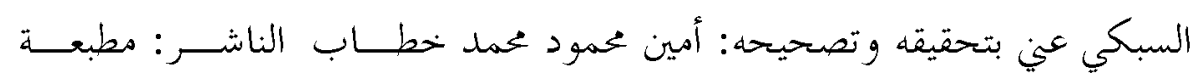

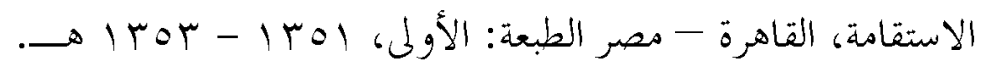

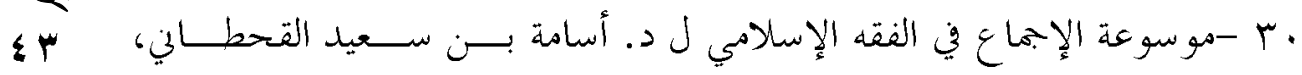
وآخرين نشر دار الفضيلة للنشر والتوزيع، الرياض - المملكة العربيــة الســـودية

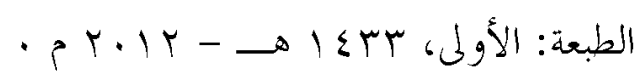
الهوامش والإحالات : الاون

$$
\begin{aligned}
& \text { ( ) هذيب الكمال / }
\end{aligned}
$$

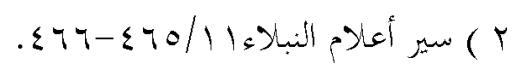

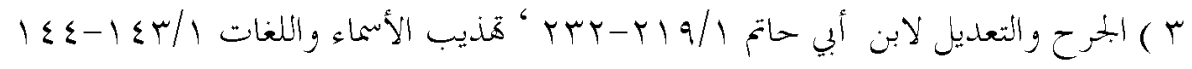

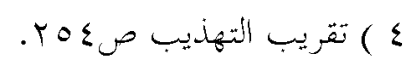

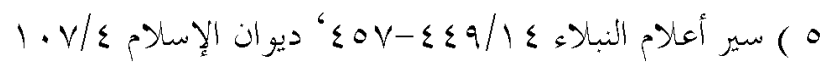

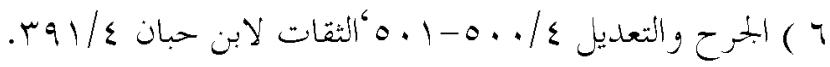

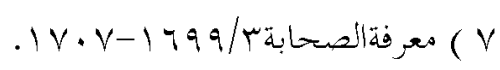

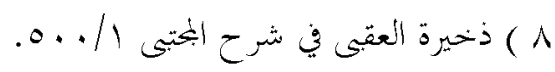




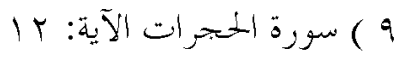

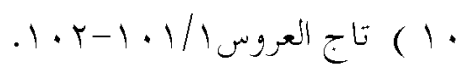

$$
\begin{aligned}
& \text { - roy-roo/lr (1) }
\end{aligned}
$$

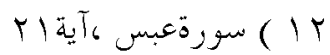

$$
\begin{aligned}
& \text { r } \\
& \text { (1) }
\end{aligned}
$$

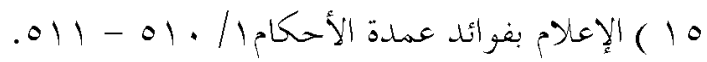

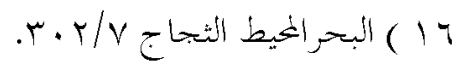

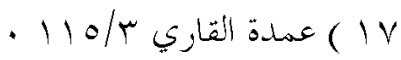

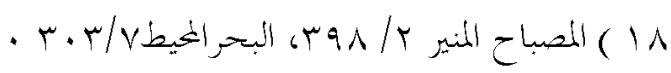

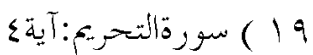

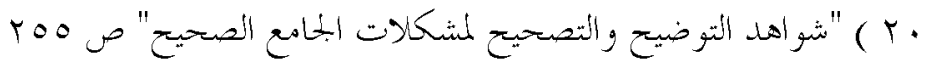

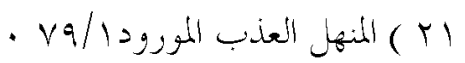

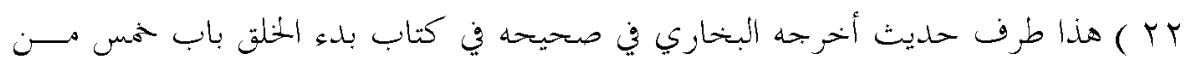

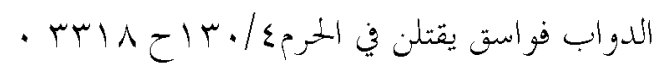

$$
\text { س (T) مورة النورآيةه }
$$

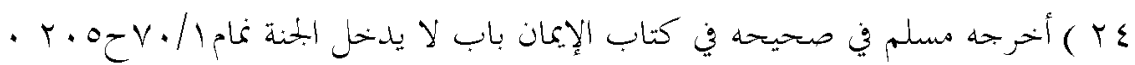

$$
\text { • Vq/1 }
$$

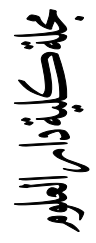

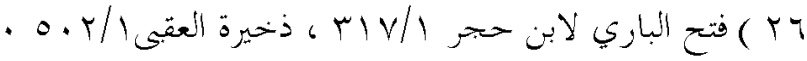

.

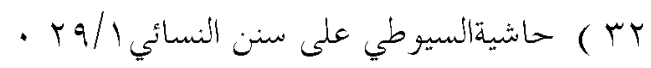

•

•

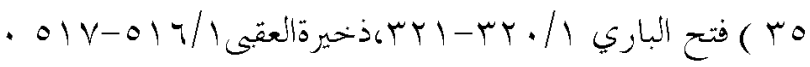




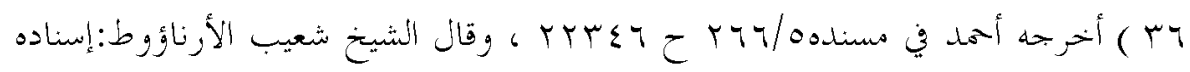
ضعيف جدا.

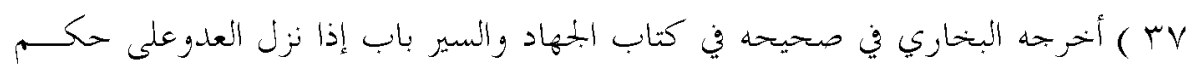

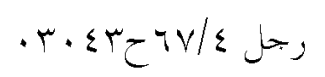

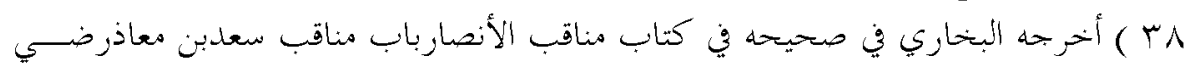

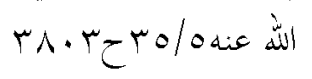

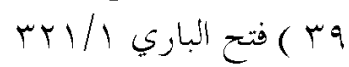

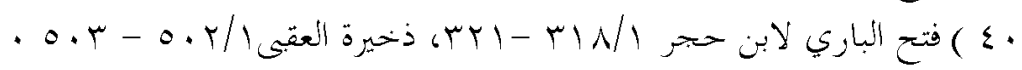

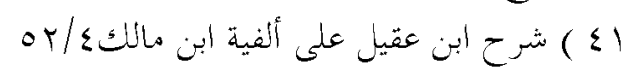

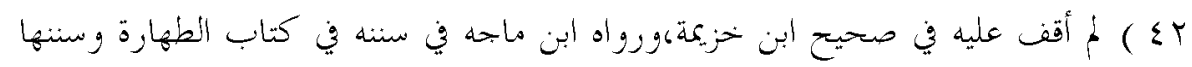

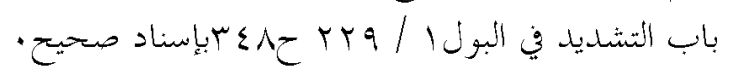

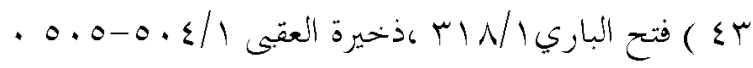

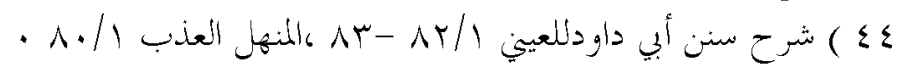

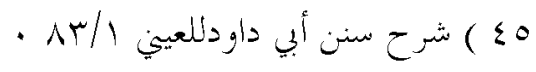

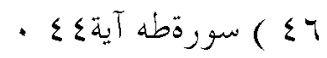

$\overline{3}$
3
0

- سورةعبس آية (

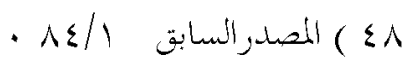

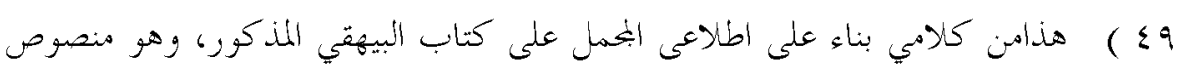
عليه ضمن المصادر. 1. C.

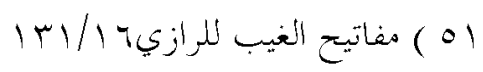

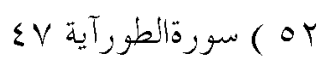

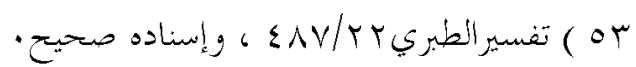

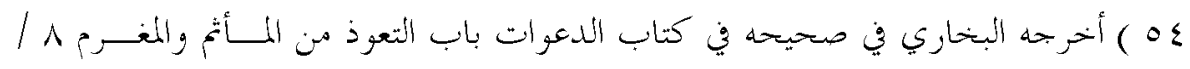

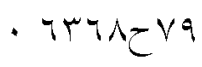

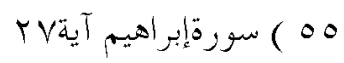

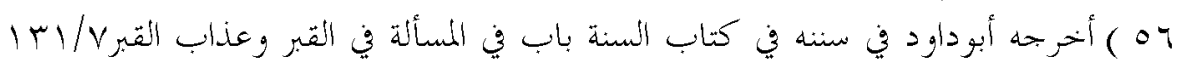
ل 


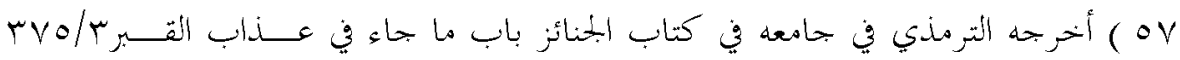

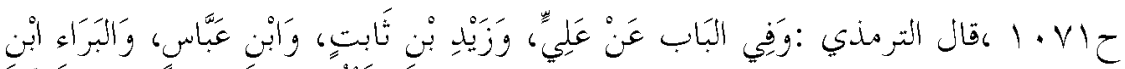

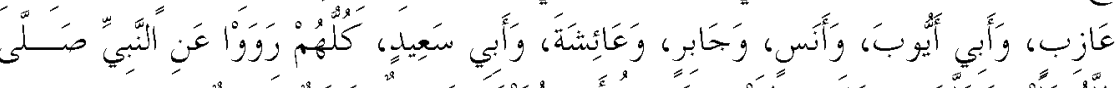

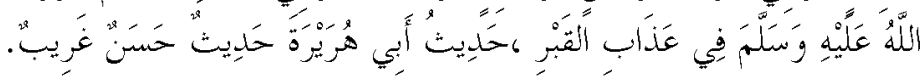

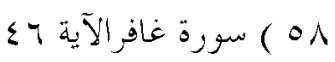

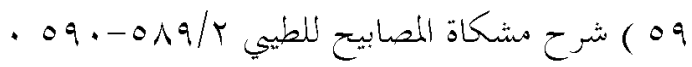

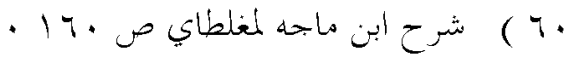

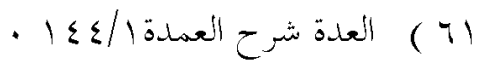

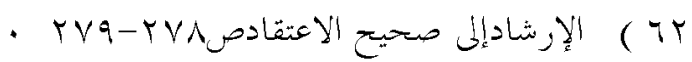

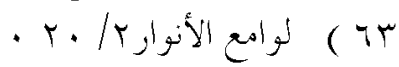

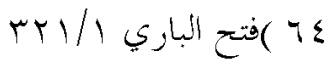

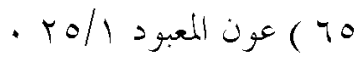

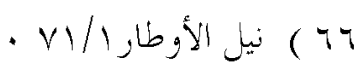

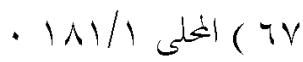

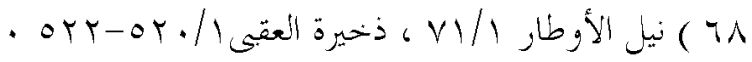
. $009 / r / 4)$ ( 79 ( V.

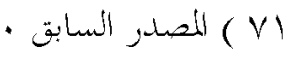

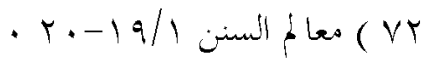

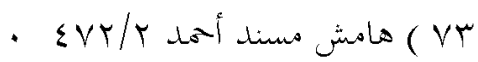

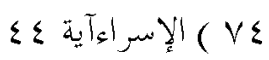

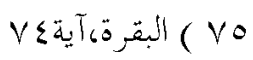

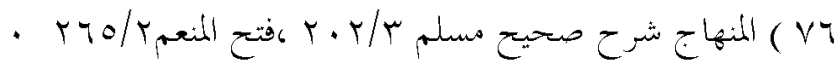

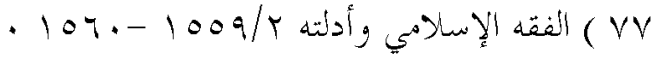

